\title{
Chapter 5 \\ Exploring Diversity in the Relationships \\ Between Teacher Quality and Job \\ Satisfaction in the Nordic Countries- \\ Insights from TALIS 2013 and 2018
}

\author{
Kajsa Yang Hansen, Jelena Radišić, Xin Liu, and Leah Natasha Glassow
}

\begin{abstract}
Equity and quality are the common goals to strive for in the Nordic education systems. Yet the mechanisms through which the separate education systems approach these goals have become more diverse. The chapter provides evidence in support of the different facets of teacher quality, such as self-efficacy, as well as teacher-students relations concerning their importance for teachers' job satisfaction across the Nordic countries. Diversities, however, were also observed. The results from the TALIS 2013 model outlined two subgroups of the Nordic countries with similar mechanisms: the Norway-Sweden and the Denmark-Finland groups. No distinctive group was found in the TALIS 2018 results, producing more countryspecific patterns, such as the importance of social utility value for Norway, adverse classroom composition in Sweden or teacher effective professional development positively impacting the personal and social utility values of teachers in Finland. These observed diversities and changing patterns may find their reasons in the gradually dissolved unity of the Nordic model by the different reform actions taken in recent years, such as in the example of Sweden, and in the long-term prerequisites for the teaching profession, where Finland is the country that stands out.
\end{abstract}

Keywords Teacher quality $\cdot$ Job satisfaction $\cdot$ TALIS $\cdot$ Nordic countries

\footnotetext{
K. Yang Hansen $(\bowtie) \cdot$ L. N. Glassow

Department of Education and Special Education, University of Gothenburg,

Gothenburg, Sweden

e-mail: kajsa.yang-hansen@ped.gu.se

J. Radišić

Department of Teacher Education and School Research, University of Oslo, Oslo, Norway

X. Liu

Department of Educational Studies, Ghent University, Ghent, Belgium
} 
Access to highly qualified, skilled and experienced teachers is viewed as a crucial contributing factor in ensuring quality and equity in education and achieving optimal outcomes for each and every student (e.g., Blömeke, Olsen, \& Suhl, 2016; Goe, 2007). However, when student composition and background are accounted for, the achievement gap portrays a different story. Differences between students at-risk, minority students and students in high-poverty areas and those not struggling with any of such difficulties are still noticeable, despite being high on the agenda for many education systems worldwide (Organisation for Economic Co-operation and Development [OECD], 2019a). Even in the Nordic countries, which are viewed as being among the most equitable systems in the world, what were once common patterns in student outcomes (see, e.g., Gustafsson \& Blömeke, 2018) are being blurred by a trend of increasing socioeconomic achievement gaps (e.g., Chmielewski, 2019; OECD, 2019a). This could imply that different educational policies and practices may be in play across the Nordic education systems. Although pursuing educational quality and equal opportunity to all remains the common goal, differences in how schools and teachers cater to the needs of different student needs may very well exist. In the process, both schools and teachers may encounter different obstacles; in this context, retaining quality teachers who enjoy their profession and are able to answer to the needs of diverse students remains a constant need.

Teacher quality enters the spotlight every time a question is raised as to how schools ensure the optimal outcomes of their students or provide an optimal learning environment (Darling-Hammond, 2017). However, despite a long tradition in investigating the concept of teacher quality, there is no consensus regarding a comprehensive definition that gathers all its constituents. Instead, the quality includes what a teacher is, has and does, thus encompassing his or her qualifications (e.g., years of experience, specialisation, professional development), characteristics (e.g., professional self-efficacy, values and beliefs) and teaching practices (Goe, 2007). Over the years, many studies have dedicated their efforts on linking the different aspects of teacher quality to student learning outcomes (e.g., Nye, Konstantopoulos, \& Hedges, 2004; Scherer \& Nilsen, 2016; Zee \& Koomen, 2016). However, the results related to these different facets are far from conclusive (Alvunger, Sundberg, \& Wahlström, 2017), showing both direct and indirect links (e.g., the relationship between teacher qualifications and student outcomes may be mediated by instructional quality; Reimer et al., 2018). Other strands have centred their efforts on connecting teachers' perceptions of their own professions, such as job satisfaction and working environment, with the quality of student learning and outcomes, focusing primarily on diversity related to student social or migration background (Banerjee, Stearns, Moller, \& Mickelson, 2017; Dicke et al., 2020).

Against this background, we investigate how different aspects of teacher quality contribute to job satisfaction. The diversity of the school environments concerning student composition and outcomes are taken into account. In particular, we wish to examine whether the determined mechanisms are alike across the Nordic countries and if the same patterns are consistent over time. The Teaching and Learning International Survey's (TALIS) data from 2013 and 2018 (OECD, 2013a, 2019b) are used for this purpose. 


\subsection{Diverse Faces of Teacher Quality}

Research on teacher quality and effectiveness takes place at the crossroads of somewhat diverse disciplines such as econometrics, psychology and sociology (Reimer, 2019). Within each field, particular contributions may be found in understanding the idea of teacher quality and its impact on students' outcomes. With this in mind, we remain aware of the complex nature of the concept of teacher quality and observe it as the interplay between teachers' qualifications, characteristics and practices of teaching (Goe, 2007).

Along the lines of the sociology of education, Coleman et al.'s report (Coleman et al., 1966) was probably one of the most forceful push-in pieces discussing the impact of schools and teachers on students achievement and the extent to which education systems are responsible for closing the gap between different social groups. Bourdieu's (1990) ideas have also contributed to the discussion; he argued that schools and teachers, because of their direct contact with the students, only assist in the reproduction of already existing inequalities by favouring a particular habitus (i.e., students who come to classrooms with particular individual upbringings and cultural competences).

The field of econometrics, on the other hand, views the education process through the lens of input-output relations, where students' outcomes lie at the end and teachers (with their own experiences and qualifications) are situated at the beginning of the process (Hanushek, 2008). Nevertheless, within such an approach, the characteristics that seem to be the easiest to measure (e.g., teacher qualifications and experience) often contribute the least in explaining the variance in teacher quality (Hanushek \& Rivkin, 2012). The education and psychology lenses take another turn, covering a myriad of topics about different aspects of teacher quality and the teaching profession. Among these, the idea of teachers' professional knowledge and practice, starting with Shulman's differentiation (Shulman, 1986; Shulman, 1987), has slowly led to a profound investigation to understand content mastery concerning the subject that one teaches (i.e., content knowledge) and how this translates into particular instructional repertoire (i.e., pedagogical content knowledge; Baumert et al., 2009; König et al., 2016). Although studies show teacher mastery does increase with years of service (Fischer et al., 2018; Nye et al., 2004), both mastery and practice have been linked to student outcomes (e.g., Baumert et al., 2009; Desimone, Smith, \& Phillips, 2013; Varghese, Garwood, Bratsch-Hines, \& VernonFeagans, 2016).

Adjacent to these investigations are the attempts in mapping out teachers' beliefs about teaching and learning (Pajares, 1992), which are seen as essential determinants of teachers' everyday practice (Buehl \& Beck, 2015). Among them, constructivist beliefs (i.e., viewing students as active participants in the process of knowledge coconstruction; Berger \& Lê Van, 2019) have been associated with higher levels of self-efficacy and instructional practices that are more grounded in constructivism (Nie, Tan, Liau, Lau, \& Chua, 2012). A vital contribution to these ideas is found in the work of Blömeke, Gustafsson, and Shavelson (2015), who developed a 
competency framework that gathers the aforementioned aspects together with those of the self-related beliefs teachers hold of the profession, their motivation and their practices.

Among the different self-related beliefs, self-efficacy (i.e., teachers' beliefs of their capability to perform particular tasks concerning teaching at a desired level of quality; Dellinger, Bobbett, Olivier, \& Ellett, 2008) has been given much attention in the research on teacher quality. Consistently, teacher self-efficacy has been associated with teachers' professional practices (Vieluf, Kuenther, \& van de Vijver, 2013; Zee \& Koomen, 2016) and student outcomes (Caprara, Barbaranelli, Steca, \& Malone, 2006; Zee \& Koomen, 2016), as well as overall job satisfaction (Caprara, Barbaranelli, Borgogni, \& Steca, 2003; Vieluf et al., 2013) and commitment to the profession (Chesnut \& Burley, 2015; Zee \& Koomen, 2016). Also, general teacher self-efficacy has been linked to student-specific efficacy, thus affecting the teacherstudent relationship (Schwab, 2019). Together with self-efficacy, motivational constructs appear to hold an important position in examining the different facets of teacher quality and their mutual associations (i.e., motivation and practice; Reimer, 2019). Although different theoretical approaches may be used (e.g., Ryan \& Deci, 2000; Eccles \& Wigfield, 2002), conceptualisations built on Eccles' work are often used because of their value component. For example, Richardson and Watt (2006, 2016) differentiated between personal utility value (i.e., the value teachers place on the personal aspects of a teaching career) and social utility value (i.e., the utility and future outcomes of working with children and adolescents). The latter, social utility value, is seen as the consistent, positive predictor of professional engagement and job satisfaction (Torsney, Lombardi, \& Ponnock, 2019).

Although mastery remains linked to teachers' experiences, similar associations are found between teacher professional development and practice (Fischer et al., 2018). It is argued, though, that more effective development programmes provide opportunities for teacher collaboration, focus on content, use affordance of the local context and offer sustained support and active participation in the context of professional learning (Akiba \& Liang, 2016; Correnti, 2007; Matsumura, Garnier, \& Resnick, 2010; Penuel, Fishman, Yamaguchi, \& Gallagher, 2007; Roth et al., 2011).

Collaborative practices (Wang, Chen, Luo, Li, \& Waxman, 2018) are also conducive to teacher job satisfaction, that is, how teachers perceive actual job outcomes compared with their desired ones (Griffith, 2004). Besides these, many factors have been linked to teacher job satisfaction (Wang, Li, Luo, \& Zhang, 2019): perception of the teachers' self-efficacy (Caprara et al., 2006; Skaalvik \& Skaalvik, 2014; Wang et al., 2019; Zee \& Koomen, 2016), the teacher-student relationship (Collie, Shapka, \& Perry, 2012; Gil-Flores, 2017; Veldman, van Tartwijk, Brekelmans, \& Wubbels, 2013), the proportion of students with a lower socioeconomic status (Matsuoka, 2015; Wang et al., 2019) and the organisational culture and working conditions (Banerjee et al., 2017; Liu \& Verblow, 2019). Here, the results on the relationship between teachers' demographic characteristics and job satisfaction are inconsistent. For example, some studies demonstrate a positive correlation between years of work experience and satisfaction (Ferguson, Frost, \& Hall, 2012; GilFlores, 2017), while others provide just the opposite (e.g., Skaalvik \& Skaalvik, 
2009). In turn, job satisfaction is linked to teachers' occupational well-being, motivation and retention (Dicke et al., 2020), while the educational background of the teacher does not seem to be linked to job satisfaction (Wang et al., 2018).

Taken together, the different faces of teacher quality show interdependence and both direct and indirect associations with student outcomes, student composition and teacher job satisfaction (Dicke et al., 2020). Although a significant number of national-level studies have been conducted (e.g., Fischer et al., 2018), the TALIS data open a new possibility for fruitful cross-country comparisons on the subject (e.g., Liu \& Verblow, 2019; Vieluf et al., 2013). At the same time, the data aid in examining the extent to which previously determined relationships hold across different countries and time points (Reimer, 2019). In this way, concrete theoretical assumptions may be tested across different contexts, and the results of such analyses may provide more nuanced insights into these relationships, thus paving the way for more attuned interventions and future investigations.

\subsubsection{The Nordic Lens on Equity and Teacher Quality}

In the years after World War II, the idea of equity while providing education at large was widespread across numerous education systems in Europe. The idea has accumulated momentum, and it became the foundation of the Nordic model. Under this model, schools ought to be inclusive, comprehensive, with no streaming and a smooth transition between the levels (Blossing, Imsen, \& Moos, 2014; Husén, 1989; Imsen, Blossing, \& Moos, 2017; Lundahl, 2016). In this model, the state is seen as a device that can provide equal opportunities to all children but not necessarily ensuring the equality of outcomes. Instead, the differences in students' outcomes were expected to be unrelated to their background or socioeconomic circumstances (Espinoza, 2007; OECD, 2018). All in all, during this time, education was seen as an essential device contributing to economic growth, minimising societal differences and promoting social mobility.

With the influx of neoliberal thinking and the economic trends at the end of the 1980s, the Nordic education systems were inevitably influenced by these concepts (Imsen et al., 2017). The neoliberal movement has led to profound debate on the sustainability of the Nordic system (Antikainen, 2006). Meanwhile, it was acknowledged that some significant differences regarding particular policies do exist across the Nordic countries (Volckmar \& Wiborg, 2014). In Sweden, the policies included extensive decentralisation and deregulation reforms, the introduction of publicfunded, private-run, for-profit and independent schools (Blossing \& Söderström, 2014), along with severe marketisation (Lundahl, 2016). These policies left their toll, leading Sweden to lag behind in rankings of the most equitable school systems of the Nordic countries (Imsen et al., 2017). Until now, the Norwegian education policy has withstood its restrictive stance on the privatisation of the school market (Imsen \& Volckmar, 2014). Still, it is not immune to accountability practices, which have been gradually introduced (Imsen et al., 2017). In Denmark, the competitive 
discourse has become stronger (Rasmussen \& Moos, 2014), while in Finland, polarisation between the schools became evident both in the equity of provision (i.e., the unequal distribution of municipality funds) and in the socioeconomic backgrounds of the students (Ahonen, 2014).

The global push towards educational measurement and comparison since the 1990s has introduced more visible accountability practices in all the Nordic countries (Wallenius, Juvonen, Hansen, \& Varjo, 2018; Wollscheid \& Opheim, 2016). The establishment of quality assurance systems has produced more extensive documentation of the work both the schools and teachers do (Imsen \& Volckmar, 2014). This has profoundly influenced how the teachers view their profession, and what they do has become more regulated and scrutinised. Comparisons across the Nordic countries indicate the job satisfaction of teachers in Sweden is the lowest among their Nordic colleagues (Taajamo, 2016), while teachers in Finland strongly believe their profession is valued in society (Reimer, 2019). Overall, substantial variations across the Nordic countries may be found regarding teachers' beliefs of the profession, perceptions of their instructional practices and perceived appreciation. Involvement in different types of professional development activities remains a challenge. The opportunities offered, as well as their variety, do not seem to provide enough of an incentive to the teachers (Taajamo, 2016), although Finland stands out both in the prerequisites for the teaching profession (Aspfors, Hansen, \& Ray, 2014) and the long tradition in linking practice with research (Wollscheid \& Opheim, 2016).

The ideas of the Nordic model remain the backbone in understanding the purpose of education and the role teachers may have in the education process. However, to fully comprehend diversity and its effects on the potential mechanisms that affect teacher quality, we need to take into account the ongoing processes in each of the Nordic systems, as well as how these may affect the strength and direction of the relationship between teacher quality, job satisfaction and educational outcomes.

\subsection{The Present Study}

Documenting a comprehensive overview of all the relevant aspects pertinent to teacher quality and views of the profession is beyond the scope of this chapter. Nonetheless, the literature review grounds our work and showcases the line of thinking that guided us in the current analyses. At the same time, we use the affordances of the TALIS data in examining the same type of mechanisms (see Fig. 5.1) across four Nordic countries (i.e., Denmark. Finland, Norway and Sweden) in both 2013 and 2018. In this way, we are also able to follow the extent to which associations in the data are relevant to particular contexts or across them.

In this investigation, we focus on the distinctive mechanisms that are found among several major aspects of teacher quality (i.e., teacher qualifications, professional development, beliefs, practices, self-efficacy) in an attempt to understand diversity in the relationships among them and how each contributes to teachers' job satisfaction. In line with the theoretical review and empirical background presented, 


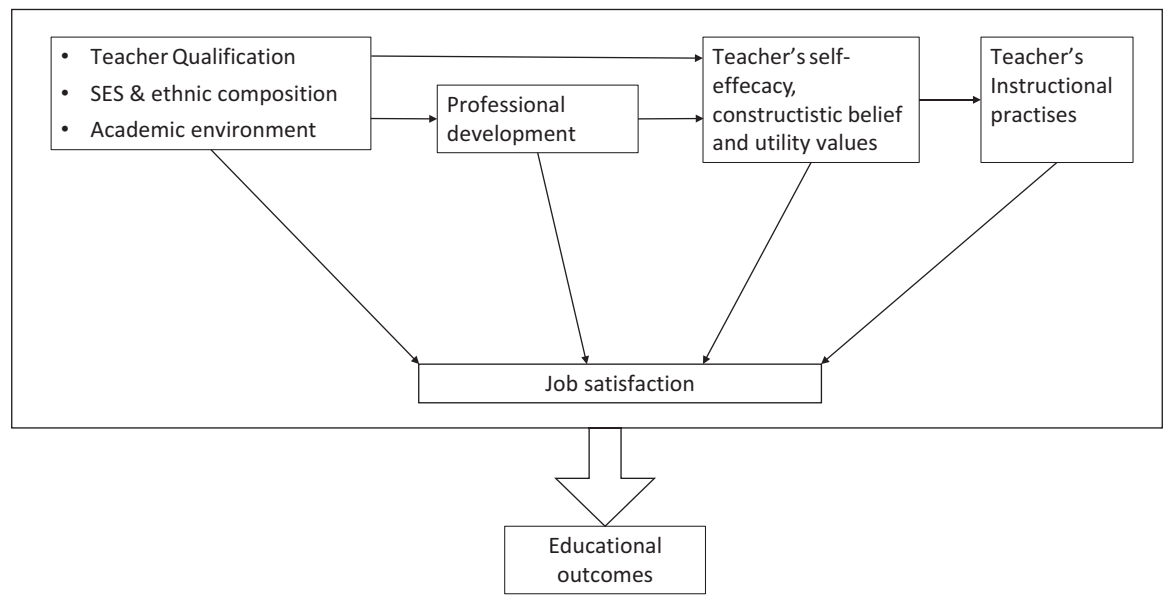

Fig. 5.1 A hypothesis model of the mechanisms among teacher quality, working environment, professional development, self-efficacy and beliefs, teaching practices and job satisfaction

we hypothesise job satisfaction is influenced by the perception of one's self-efficacy (Caprara et al., 2006; Skaalvik \& Skaalvik, 2014; Vieluf et al., 2013; Zee \& Koomen, 2016; Wang et al., 2019), professional development and collaborative practices (Fischer et al., 2018; Wang et al., 2018) and utility values (Torsney et al., 2019). The influence of teacher qualifications, here combining years of service and education (e.g., Gil-Flores, 2017; Wang et al., 2018), the teacher-student relationship (Collie et al., 2012; Gil-Flores, 2017; Veldman et al., 2013), academic environment in the classroom and the proportion of students with a lower socioeconomic status (SES) in the classroom (Matsuoka, 2015; Wang et al., 2019) also are included in the model. Figure 5.1 shows the hypothetical model that was tested using both TALIS 2013 and 2018 data. In this way, both the direct and mediating effects can be examined. The relationships are tested separately for each of the Nordic countries.

Within the last two TALIS cycles, somewhat differing information concerning teachers' beliefs, values and instructional practices has been collected. Therefore, the hypothesised model is operationalised in a slightly different way across the two. Because TALIS does not collect information on educational outcomes, only part of the hypothesis model in the rectangular frame is tested. However, the model controls for teachers' perceptions of their classroom academic and demographic environments, which are made up of the proportions of students with special needs and those with disadvantaged SES and migration backgrounds. 


\subsection{Method}

\subsubsection{Participants}

Four Nordic countries (i.e., Denmark, Finland, Norway and Sweden) joined both the TALIS 2013 and 2018 cycles. Information about the samples used in the analyses is provided in Table 5.1 and is displayed by the countries analysed. Additional technical details on the sample may be found in the TALIS technical reports (OECD, 2013b, 2019c).

\subsubsection{Variables}

The two consecutive TALIS cycles gathered various information about different aspects of the teaching profession and their related characteristics and practice. The following variables were included in the 2013 model.

Teacher's professional self-efficacy is a composite variable encompassing efficacy in classroom management, efficacy in instruction and efficacy in student engagement, gathering 12 items in total. Each item is on a four-point scale with the response categories ranging from 'not at all' to 'a lot'.

The teacher's job satisfaction is made up of two subscales describing their satisfaction with the current work environment and with the teaching profession. Both subscales amount to eight four-point items, with the response alternatives ranging from 'strongly disagree' to 'strongly agree'.

Teacher-student relations is an index measure set on a four-point scale with four items. The response categories include a range from 'strongly disagree' to 'strongly agree' on items focusing on aspects such as whether the teachers and students usually get on well with each other.

The index of constructivist beliefs was measured by four items using a four-point scale, with response categories ranging from 'strongly disagree' to 'strongly agree' The items included inquiring about the perceptions of the role of teachers in facilitating students' inquiry or the best ways students may be learning.

Teacher's effective professional development is a four-item composite score set on a four-point response scale ranging from 'not in any activities' to 'yes, in all

Table 5.1 The number of teachers and schools in the Nordic countries in TALIS 2013 and 2018

\begin{tabular}{|c|c|c|c|c|}
\hline & \multicolumn{2}{|c|}{ TALIS 2013} & \multicolumn{2}{|c|}{ TALIS 2018} \\
\hline & Teachers & Schools & Teachers & Schools \\
\hline Denmark & 1649 & 148 & 1853 & 141 \\
\hline Finland & 2739 & 146 & 2761 & 148 \\
\hline Norway & 2981 & 145 & 3802 & 185 \\
\hline Sweden & 3193 & 186 & 2488 & 180 \\
\hline Total & 10562 & 625 & 10904 & 654 \\
\hline
\end{tabular}


activities'. The compound construct focuses on the different opportunities for active learning methods or collaborative learning activities or research with other teachers.

Teacher collaboration is an index measure focusing on the opportunities for collaboration with different stakeholders or activities (e.g., teach jointly as a team in the same class). The six-item response options of the index range are from 'never' to 'once a week or more'.

Teacher qualification is a principle component factor score comprised of the highest level of teacher formal education, completion of teacher training programme and years of work experience.

Classroom composition of SES and migration is a principle component factor score of the percentage students whose first language is not the native language and who are from socioeconomically disadvantaged homes.

Classroom academic environment is a principal component factor score of the percentage of students with special needs, low achievement, behavioural problems and among the less gifted. Table 5.2 provides more details of the constructs used, including where these constructs differ between the 2013 and 2018 cycles.

Table 5.2 Descriptive statistics of the variables in the analysis for TALIS 2013 and TALIS 2018

\begin{tabular}{|c|c|c|c|c|c|c|c|c|}
\hline \multirow[b]{2}{*}{ TALIS 2013} & \multicolumn{2}{|c|}{ Demark } & \multicolumn{2}{|c|}{ Finland } & \multicolumn{2}{|c|}{ Norway } & \multicolumn{2}{|c|}{ Sweden } \\
\hline & Mean & SD & Mean & SD & Mean & SD & Mean & SD \\
\hline $\begin{array}{l}\text { Teacher's professional } \\
\text { self-efficacy }\end{array}$ & 13.33 & 1.39 & 11.86 & 1.85 & 11.38 & 1.47 & 12.23 & 1.63 \\
\hline Teacher's job satisfaction & 12.60 & 1.83 & 12.35 & 1.78 & 12.25 & 1.70 & 11.40 & 1.96 \\
\hline Teacher-student relations & 14.73 & 1.79 & 13.47 & 1.93 & 14.11 & 1.98 & 14.04 & 1.81 \\
\hline Teacher's constructive beliefs & 13.42 & 1.74 & 12.69 & 1.58 & 11.72 & 1.05 & 11.06 & 1.37 \\
\hline $\begin{array}{l}\text { Teacher's effective professional } \\
\text { development }\end{array}$ & 9.23 & 2.04 & 8.39 & 1.70 & 7.57 & 1.63 & 8.38 & 1.98 \\
\hline Teacher collaboration & 10.94 & 1.63 & 9.26 & 1.62 & 10.30 & 1.67 & 10.78 & 1.48 \\
\hline Teacher qualification & 0.06 & 0.94 & 0.04 & 0.92 & 0.08 & 0.85 & -0.13 & 1.18 \\
\hline $\begin{array}{l}\text { classroom SES and migration } \\
\text { composition }\end{array}$ & -0.15 & 1.03 & -0.19 & 0.89 & 0.01 & 0.86 & 0.22 & 1.13 \\
\hline Classroom academic environment & -0.22 & 1.08 & 0.11 & 1.07 & 0.04 & 0.82 & -0.02 & 1.02 \\
\hline TALIS 2018 & Mean & SD & Mean & SD & Mean & SD & Mean & SD \\
\hline $\begin{array}{l}\text { Teacher's professional } \\
\text { self-efficacy }\end{array}$ & 11.19 & 1.81 & 11.08 & 1.74 & 11.15 & 1.71 & 11.17 & 1.88 \\
\hline Teacher's personal utility values & 10.37 & 2.25 & 10.43 & 2.16 & 9.96 & 1.95 & 9.92 & 2.10 \\
\hline Teacher's social utility values & 12.10 & 2.01 & 12.01 & 2.44 & 11.75 & 1.68 & 11.68 & 2.25 \\
\hline Teacher's job satisfaction & 12.08 & 2.08 & 11.96 & 2.18 & 11.42 & 2.07 & 11.98 & 2.11 \\
\hline $\begin{array}{l}\text { Teacher's effective professional } \\
\text { development }\end{array}$ & 10.07 & 1.37 & 11.45 & 2.23 & 9.73 & 2.44 & 10.10 & 2.34 \\
\hline Teaching practice & 11.41 & 2.07 & 11.34 & 2.10 & 11.56 & 1.48 & 11.75 & 1.97 \\
\hline Teacher-student relations & 12.75 & 2.33 & 12.52 & 2.51 & 10.88 & 2.93 & 11.87 & 2.71 \\
\hline Teacher qualification & 0.04 & 0.95 & 0.00 & 0.94 & 0.00 & 1.00 & -0.18 & 1.13 \\
\hline $\begin{array}{l}\text { Classroom SES and migration } \\
\text { composition }\end{array}$ & 1.28 & 3.57 & 1.21 & 3.67 & 4.79 & 4.97 & 3.27 & 4.37 \\
\hline Classroom academic environment & 1.33 & 4.10 & 1.51 & 4.28 & 4.57 & 6.05 & 1.74 & 4.18 \\
\hline
\end{tabular}


In the 2018 model, three new variables were added to the list. These include teacher's personal utility values, teacher's social utility values and teaching practice. Teacher's constructive beliefs were excluded from the variable list.

Teacher's personal utility values is a four-item composite related to the different aspects teachers value to be part of the teaching profession (e.g., teaching offers a steady career path or teaching provides a reliable income). The scale is set on a fourpoint scale, with the response categories ranging from 'Not important at all' to 'Of high importance'.

Teacher's social utility values also relate to the different aspects teachers may value relative to the teaching profession but from the perspective of the immediate environment and community (e.g., teaching allowed me to benefit the socially disadvantaged). The scale is comprised of four items and set on a four-point range, with response categories ranging from 'Not important at all' to 'Of high importance'.

The final composite scale, teaching practice, comprises subscales on the clarity of instruction, cognitive activation and classroom management, with 12 items in total. Response options include the following: 'Never or almost never', 'Occasionally', 'Frequently' and 'Always'. All variables were used and aligned with the TALIS technical manuals (OECD, 2013b, 2019b). For more information on each scale, see the TALIS technical reports (OECD, 2013b, 2019b).

\subsubsection{Analytical Method and Data Analyses}

All analyses were performed in Mplus (Muthén \& Muthén, 1998-2017). The FIML option was used to handle missing data. In the current study, a path modelling approach was adopted to examine the mechanism through which teacher characteristics, professional belief and values and teaching practices may affect their job satisfaction. In the conditional model information on teacher experience and specialisation, student socioeconomic and immigration composition in the classroom and classroom academic environment were accounted for. One of the advantages of a path analysis is its ability to estimate the direct effects of an independent variable on a dependent variable, along with being able to estimate an indirect effect from the same independent variable through a mediator on the dependent variable (e.g., Wolfle, 1980).

The path model was specified in light of prior research evidence. We provide a simplified illustration to demonstrate this principle. In Model A, for example, teacher qualification affects the teacher's job satisfaction, which is a direct and total effect with a strength of $a$. However, according to the specified model and prior evidence, teacher qualifications may have an effect on teacher effective professional development; thus, in turn, it can impact teacher's job satisfaction (Model B). In Model B, the total effect of teacher qualification is decomposed into a direct effect from teacher qualification on their job satisfaction $a^{\prime}$ and an indirect effect. The strength of the latter is a product of two direct effects, namely, a direct effect of teacher qualification on teacher's professional development $b$ and teacher's 
professional development on their job satisfaction $c$. Thus, the total effect of teacher qualification on their job satisfaction is now the sum of the direct and indirect effects, $a^{\prime}+b c$ (e.g., Baron \& Kenny, 1986).

In Model B, the mediating effect $b c$ may account for part of the total effect between teacher qualification and job satisfaction $a$ in Model A, making the direct effect $a$ ' in Model B smaller than $a$. In a particular situation of full mediation, the mediating effect $b c$ may be overlapping entirely with the total effect $a$ in Model A. In this case, the direct effect $a^{\prime}$ in Model B is spurious.

\subsection{Results}

In this section, we focus on the relationship between teachers' professional selfefficacy, constructive beliefs, practices and job satisfaction in TALIS. We explore the relationship separately for TALIS 2013 and 2018, which is followed by a short comparison between the 2013 and 2018 results.

Both the direct effects and indirect effects are shown. The hypothesis model in Fig. 5.2 is used as a common point of departure for all countries and each TALIS cycle. Because there are two types of effects (i.e., direct effect and indirect effect) in the path analysis, the effect of an independent variable on the dependent variable needs to consider both effect types. The operational models for all the Nordic countries in both TALIS cycles are saturated, meaning that no relation between any two factors was left out. However, when presenting the parameter estimates in the path diagrams, only the statistically significant paths are included. Full estimations are provided in the supplementary material. We start by observing these mechanisms across the 2013 cycle for the four studied Nordic countries.

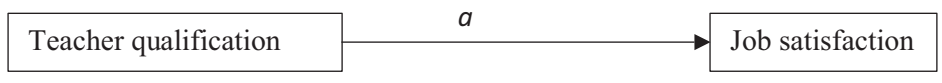

Model A

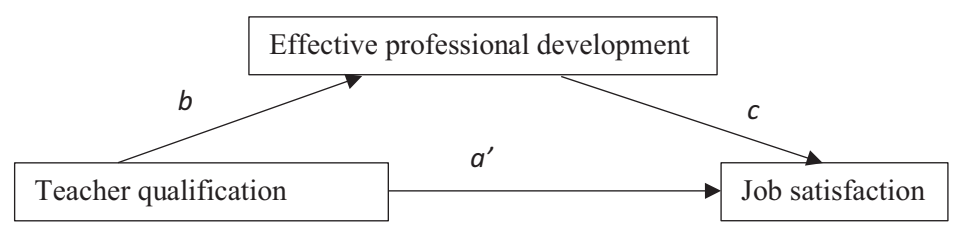

Model B

Fig. 5.2 Direct and indirect effects between teacher qualifications, teach effective professional development and teacher job satisfaction 


\subsubsection{Diverse Mechanisms in the TALIS 2013 Data}

In Sweden, all the teacher and teaching-related factors in the operationalised model for the 2013 TALIS data have a significant impact on teachers' job satisfaction. The most substantial total effect on job satisfaction (TJOBSATS) came from the teachers' self-efficacy (TSELEFFS, 0.21), where the direct effect was 0.15 and the indirect effect was 0.07. The overall effect of teachers' effective professional development (TEFFPROS) on their job satisfaction was about 0.15 , of which 0.09 was the direct effect and 0.07 was the indirect effect. Albeit statistically significant, the effects of teacher qualification (TQ) and constructivist belief (TCONSBS) were rather small. Significant direct effects of classroom SES and migration composition (SESMIG), teacher-student relations (TSCTSTUDS) and teacher collaboration (TCCOLLS) have also been observed in Sweden, at -0.07, 0.19 and 0.15, respectively. As shown in Fig. 5.3 (top diagram), teachers' qualifications (TQ), the teachers' effective professional development (TEFFPROS), self-efficacy (TSELEFFS) and teachers' constructivist beliefs (TCONSBS) have significantly affected the teachers' job satisfaction both directly and indirectly.

The 2013 model for Norway (Fig. 5.3, lower diagram) shows significant effects, both direct and indirect, from teachers' self-efficacy (TSELEFFS) and effective inservice professional development (TEFFPROS) on their job satisfaction. The highest total effect was 0.28 from self-efficacy. When decomposed, 0.16 went to the direct effect, and 0.09 was the indirect effect. Effective in-service professional development (TEFFPROS) was found to have a substantial effect on teachers' job satisfaction (TJOBSATS), 0.16 in total. This value was contributed to equally from both direct and indirect effect, each being 0.08 . Teachers' professional collaboration (TCCOLLS) held the most substantial impact on teachers' job satisfaction at 0.13 . Teacher-student relations also has a considerable effect $(0.31)$. Only a small negative direct effect $(-0.06)$ was found for classroom academic environment (CLACDEM) on teachers' job satisfaction.

In Finland, for the contextual factors, classroom SES and ethnic composition (SESMIG) and the classroom academic environment (CLACDEN), only small negative effects were found: -0.07 and -0.05 respectively. A little indirect effect was observed between teacher effective professional development (TEFFPROS) and job satisfaction (TJOBSATS). Teachers' professional self-efficacy (TSELEFFS) affected their job satisfaction both directly $(0.20)$ and indirectly (0.09). No significant effect was found for the remaining factors in the model (see Fig. 5.4).

In the case of Denmark, Fig. 5.4 indicates that TQ directly influenced the teachers' job satisfaction (TJOBSATS, -0.06). It also significantly mediated the effect of teacher professional self-efficacy (TSELEFFS, 0.05) and teacher-student relations (TSCTSTUDS, 0.01); self-efficacy and teacher professional collaboration (TEFFPROS, 0.01) also affected teachers' job satisfaction (TJOBSATS). However, these indirect effects were rather small. The most substantial direct effect was found in teacher-student relations and their job satisfaction (0.28). Teachers' professional collaboration (TCCOLLS) also was significantly related to their job satisfaction 

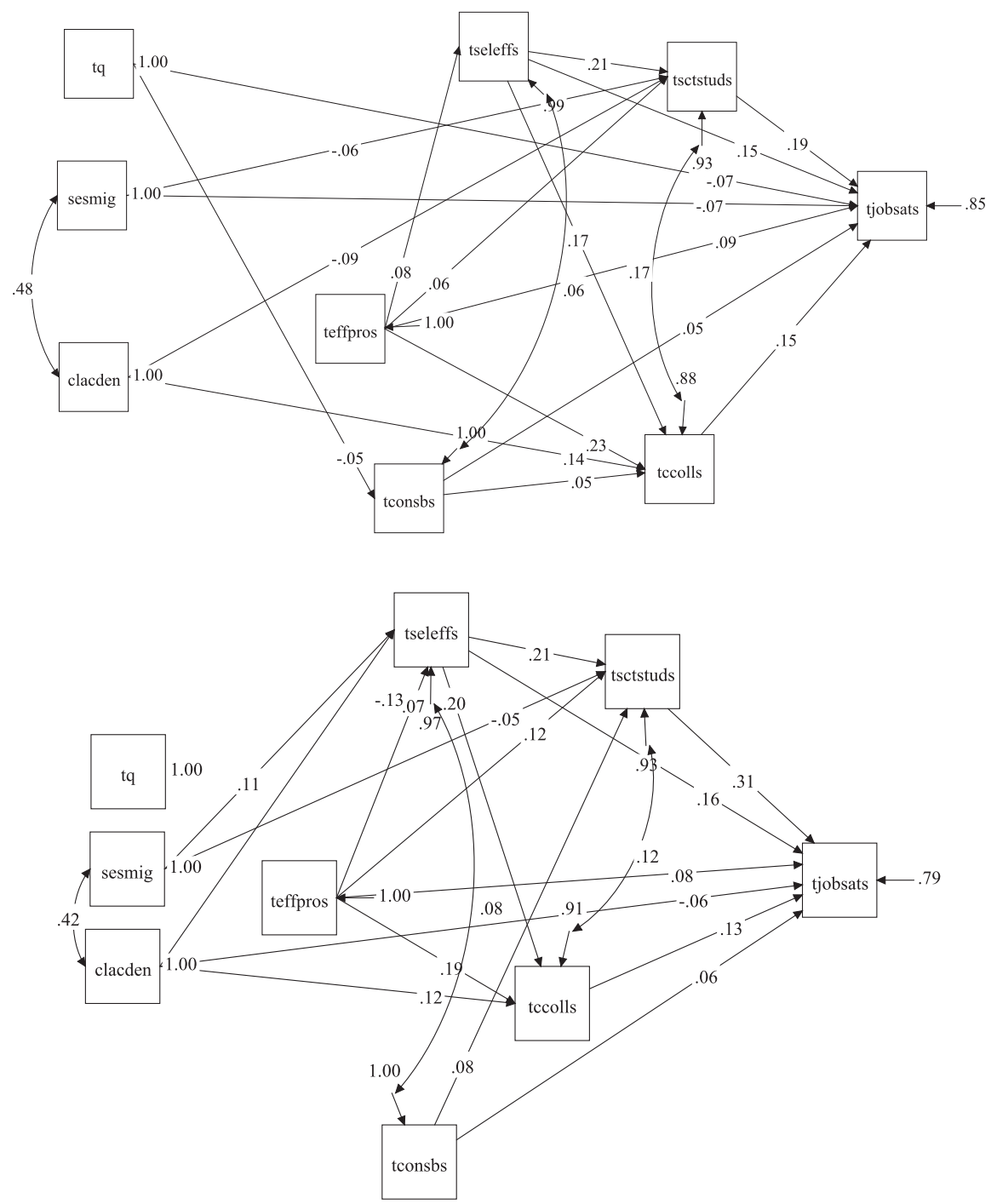

Fig. 5.3 Path diagram for Sweden (top) and Norway (down) in TALIS 2013. (Note: TSELEFFS teacher's professional self-efficacy, TJOBSATS teacher's job satisfaction, TSCTSTUDS teacherstudent relations, TCONSBS teacher's constructive beliefs, TEFFPROS teacher's effective professional development, TCCOLLS teacher collaboration, $T Q$ teacher qualification, SESMIG classroom SES and migration composition, CLACDEM classroom academic environment. Only significant paths are shown)

(0.07). For the classroom contextual factors, the SES-ethnic composition was only indirectly related to teachers' job satisfaction (TJOBSATS) through teacher-student relations (TSCTSTUDS, -0.06) and constructivist belief (TCONSBS) and teacherstudent relations (0.01). Classroom academic environment was found to have both 

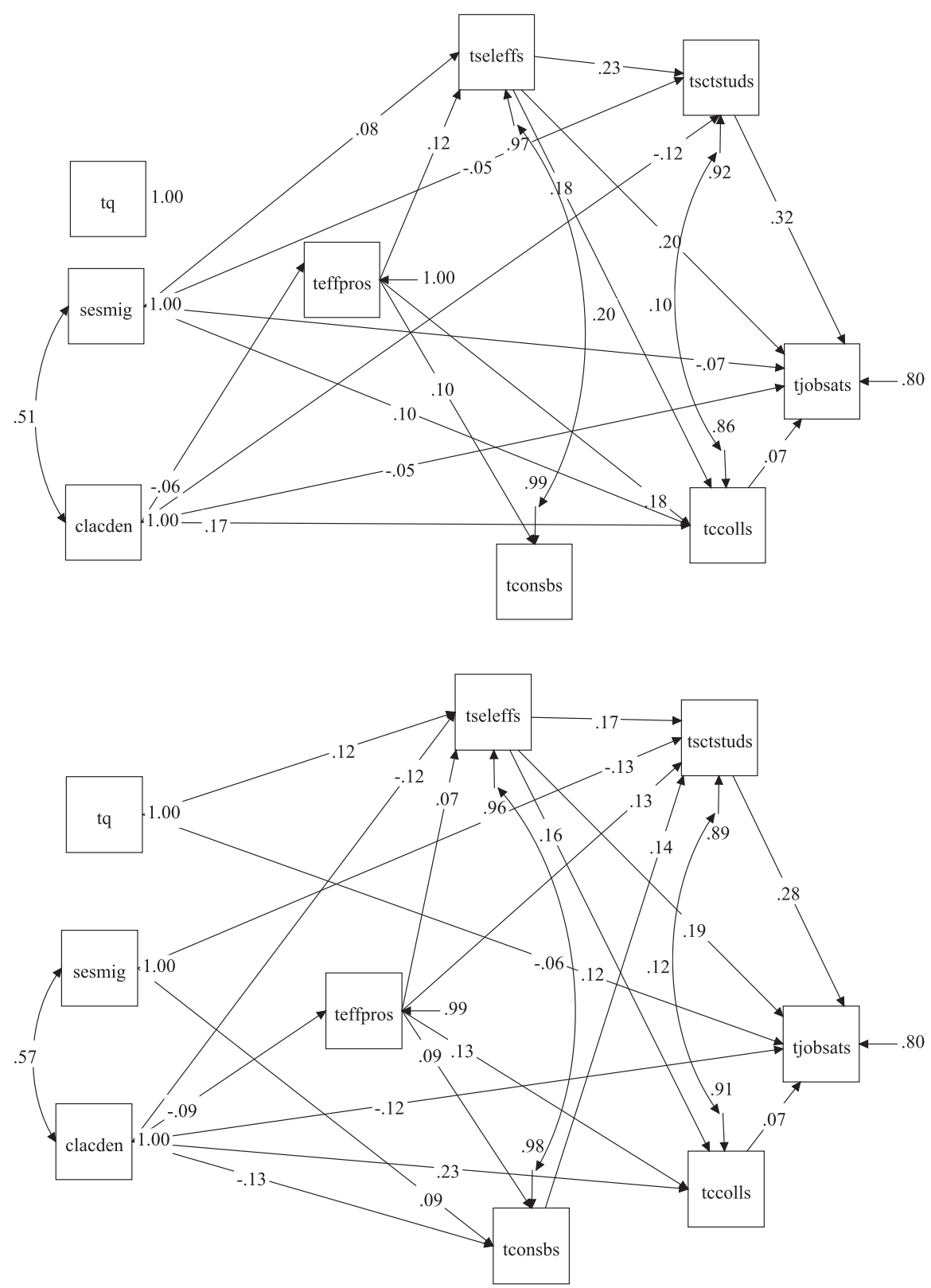

Fig. 5.4 Path diagram for Finland (top) and Denmark (down) in TALIS 2013. (Note: TSELEFFS teacher's professional self-efficacy, TJOBSATS teacher's job satisfaction, TSCTSTUDS teacherstudent relations, TCONSBS teacher's constructive beliefs, TEFFPROS teacher's effective professional development, TCCOLLS teacher collaboration, $T Q$ teacher qualification, SESMIG classroom SES and migration composition, CLACDEM classroom academic environment. Only significant paths are shown) 
a significant direct and indirect effect on teachers' job satisfaction (TJOBSATS), at -0.12 and -0.04 , respectively. For teachers' characteristics, professional selfefficacy (TSELEFFS) affected job satisfaction both directly (0.19) and indirectly through teacher-student relations and professional collaborations (0.09). Only a small indirect effect was observed from the teachers' constructivist beliefs on their job satisfaction via teacher-student relations (0.04).

Overall, different mechanisms were found across the four Nordic countries in the TALIS 2013 survey. However, some common patterns also were observed. Among them, the teachers' professional self-efficacy was one of the most significant factors affecting teachers' job satisfaction both directly and indirectly via teacher-student relations. Also, the teachers' professional development mediates the effects of their professional self-efficacy and student-teacher relations, which, in turn, affects their job satisfaction. The strongest effect on teachers' job satisfaction came from the teacher-student relations. Teachers' professional collaborations also were found to have a substantial effect, higher in Sweden and Norway than those in Denmark and Finland do. Given these common features, the four Nordic countries can be separated into two groups with similar mechanisms: Norway-Sweden group and Denmark-Finland group.

From Table 5.3, the path model can explain equally the amount of variance in teacher's job satisfaction in Denmark, Finland and Norway, at around 20\%, while it performed less well in Sweden (15\%). Different amounts of explained variances in other teacher-related factors also indicate the different pathways through which these factors are mediating and affecting job satisfaction. The variation in teachers' effective professional development cannot be attributed to any of the factors in the model in all the Nordic countries and neither can the variance of teachers' constructive beliefs in Norway and Sweden. Please see the supplementary material, appendices $\mathrm{A}-\mathrm{C}$ for the detailed specification on all the direct, indirect and total effects.

Table 5.3 Explained variance of all the endogenous variables in the path models of the four Nordic countries in TALIS 2013

\begin{tabular}{l|l|l|l|l|l|l|l|r}
\hline & \multicolumn{2}{l}{ Denmark } & \multicolumn{2}{l}{ Finland } & \multicolumn{2}{l}{ Norway } & \multicolumn{2}{l}{ Sweden } \\
\cline { 2 - 10 } & $\begin{array}{l}\mathrm{R}^{2} \\
(\%)\end{array}$ & z-value & $\begin{array}{l}\mathrm{R}^{2} \\
(\%)\end{array}$ & z-value & $\begin{array}{l}\mathrm{R}^{2} \\
(\%)\end{array}$ & z-value & $\begin{array}{l}\mathrm{R}^{2} \\
(\%)\end{array}$ & z-value \\
\hline Job satisfaction & 20 & 9.37 & 20 & 12.30 & 21 & 10.05 & 15 & 11.25 \\
\hline Teacher-student relations & 11 & 5.47 & 8 & 6.97 & 7 & 4.96 & 7 & 5.84 \\
\hline Professional collaborations & 9 & 4.88 & 14 & 8.73 & 9 & 3.21 & 12 & 9.64 \\
\hline Constructivist belief & 2 & 2.22 & 1 & 2.82 & 0 & .90 & 0 & 1.57 \\
\hline Professional self-efficacy & 4 & 3.66 & 3 & 3.42 & 3 & 3.13 & 1 & 2.11 \\
\hline $\begin{array}{l}\text { Effective professional } \\
\text { development }\end{array}$ & 1 & 1.10 & 0 & 1.46 & 0 & .48 & 0 & .72 \\
\hline
\end{tabular}




\subsubsection{Diverse Mechanisms in the TALIS 2018 Data}

Following the same assumptions grounded in prior research, the hypothesis model was operationalised with the available factors in TALIS 2018. The analyses indicated a high correlation, that is, over 0.90, between the classroom SES-ethnic composition and the academic environment for all Nordic countries. Therefore, only the classroom SES-ethnic composition was kept in the operationalised model. Again, we observe the results for each country separately

In Sweden, the highest direct effect on teacher's job satisfaction (T3JOBSA) was from teacher-student relations (T3STUD, 0.42). The disadvantaged SES-ethnic classroom composition (SESMIG) also had a relatively high direct effect (0.29). The challenging classroom composition may make Swedish teachers feel a sense of fulfilment from their work, thus contributing to their satisfaction. However, it strongly affected teacher-student relations negatively $(-0.67)$, resulting in the mediation effect on job satisfaction (T3JOBSA) via teacher-student relations to be negative $(-0.28)$. It is interesting to observe that teachers' effective professional development (T3EFFPD) was positively related to teachers' personal utility motivation (i.e., teacher profession offers a steady career path, a reliable income/secure job and good schedule, T3PERUT) by 0.35 . However, it was found to have no impact on teachers' social utility motivation (i.e., teacher's belief that teaching allows them to influence the development of children and young people, helping disadvantaged and contributing to society, T3SOCUT). Teachers' professional self-efficacy (T3SELF) indirectly affected teachers' job satisfaction (T3JOBSA) through student-teacher relations (0.31), but no significant direct effect was found. No significant direct effect was found for teaching practices (T3TPRA).

As shown in Fig. 5.5, the only significant direct effects on teachers' job satisfaction (T3JOBSA) in Norway were from teacher-student relations (T3STUD) and teachers' social utility motivation (T3SOCUT) at 0.28 and 0.14 , respectively. We also observed significant indirect effects of classroom disadvantaged SES-ethnic composition (SESMIG) on teachers' job satisfaction via teacher-student relations $(-0.11)$, teachers' social utility motivation to teach $(-0.02)$ and teachers' effective professional development and teacher-student relations (-0.04). Classroom disadvantaged SES-ethnic composition (SESMIG) directly affected all other teacherrelated factors except for the teachers' practice (T3TPRA). The highest direct effect was SESMIG on teachers' professional self-efficacy $(-0.80)$, followed by SESMIG effect on teacher-student relations (-0.41). The direct effects of SESMIG on teachers' personal and social utility motivations were also substantial at -0.20 and -0.16 , respectively. However, no relationship was found between classroom disadvantaged SES-ethnic composition (SESMIG) and job satisfaction (T3JOBSA). Effective professional development (T3EFFPD) positively affected teacher-student relations (T3STUD, 0.34), with no significant mediation effect on job satisfaction (T3JOBSA). It is worth noticing that Norwegian teachers' qualifications positively (TQ) affected their teaching practices (T3TPRA, 0.11). 

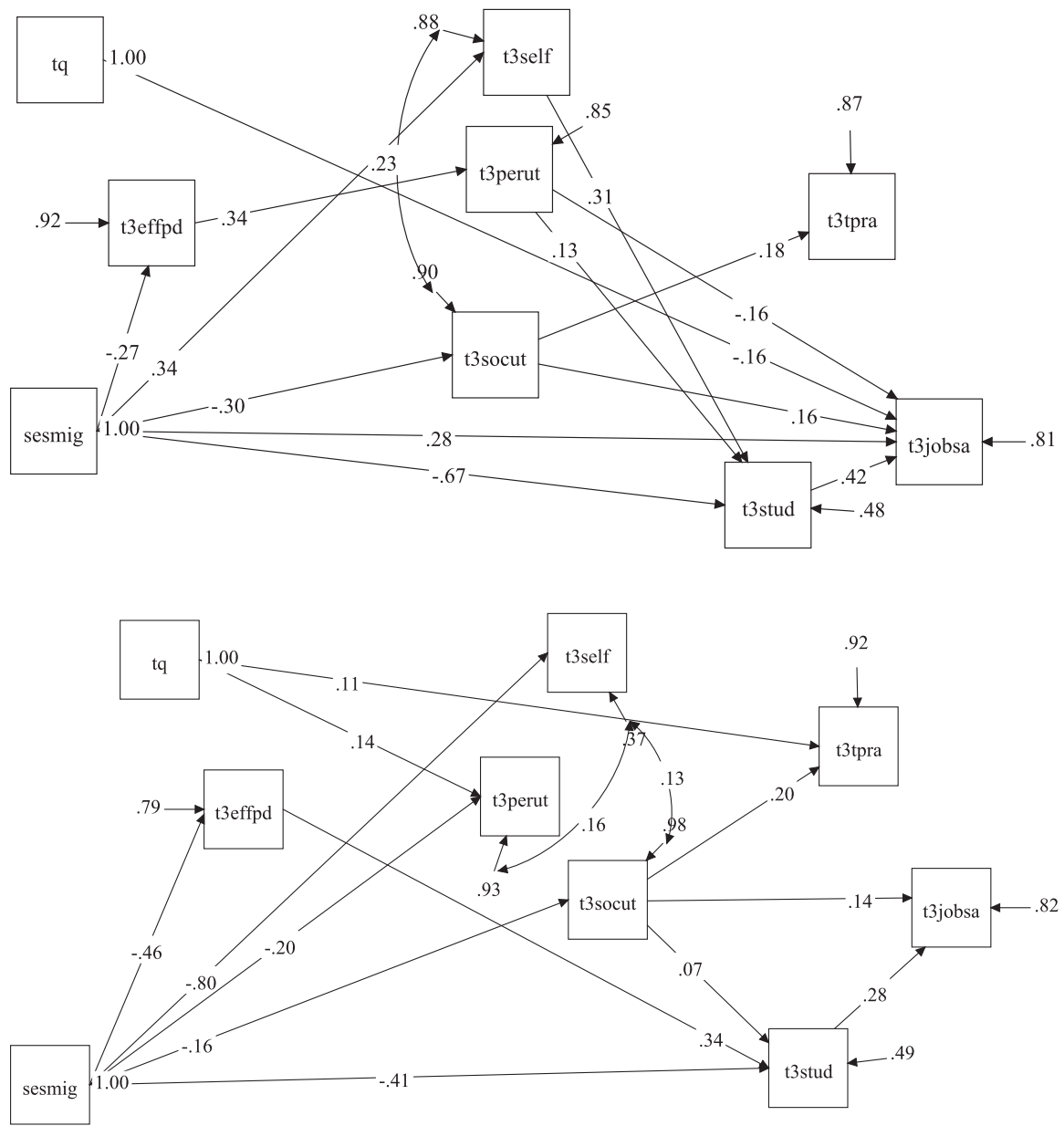

Fig. 5.5 Path diagram for Sweden (top) and Norway (down) in TALIS 2018. (Note: T3EFFPD effective professional development, T3PERUT personal utility value, T3SOCUT social utility value, T3STUD teacher-student relations, T3TPRA teaching practices, T3JOBSA job satisfaction, T3SELF teacher self-efficacy, $T Q$ teacher qualification, SESMIG classroom students SES and migration background composition. Only significant paths are shown)

In the case of Finland, the most substantial direct effect on teachers' job satisfaction (T3JOBSA) was from teacher-student relations (T3STUD, 0.21), and the effect of teachers' social utility motivation (T3SOCUT) to teach was also substantial (0.16). Disadvantaged classroom SES and ethnic composition (SESMIG) was found to have rather strong negative influences on teachers' self-efficacy (T3SELF, -0.58), effective professional development (T3EFFPD, -0.44), teacher-student relations (T3STUD, -0.50) and personal utility motivation to teach (T3PERUT, -0.18) (Fig. 5.6). 

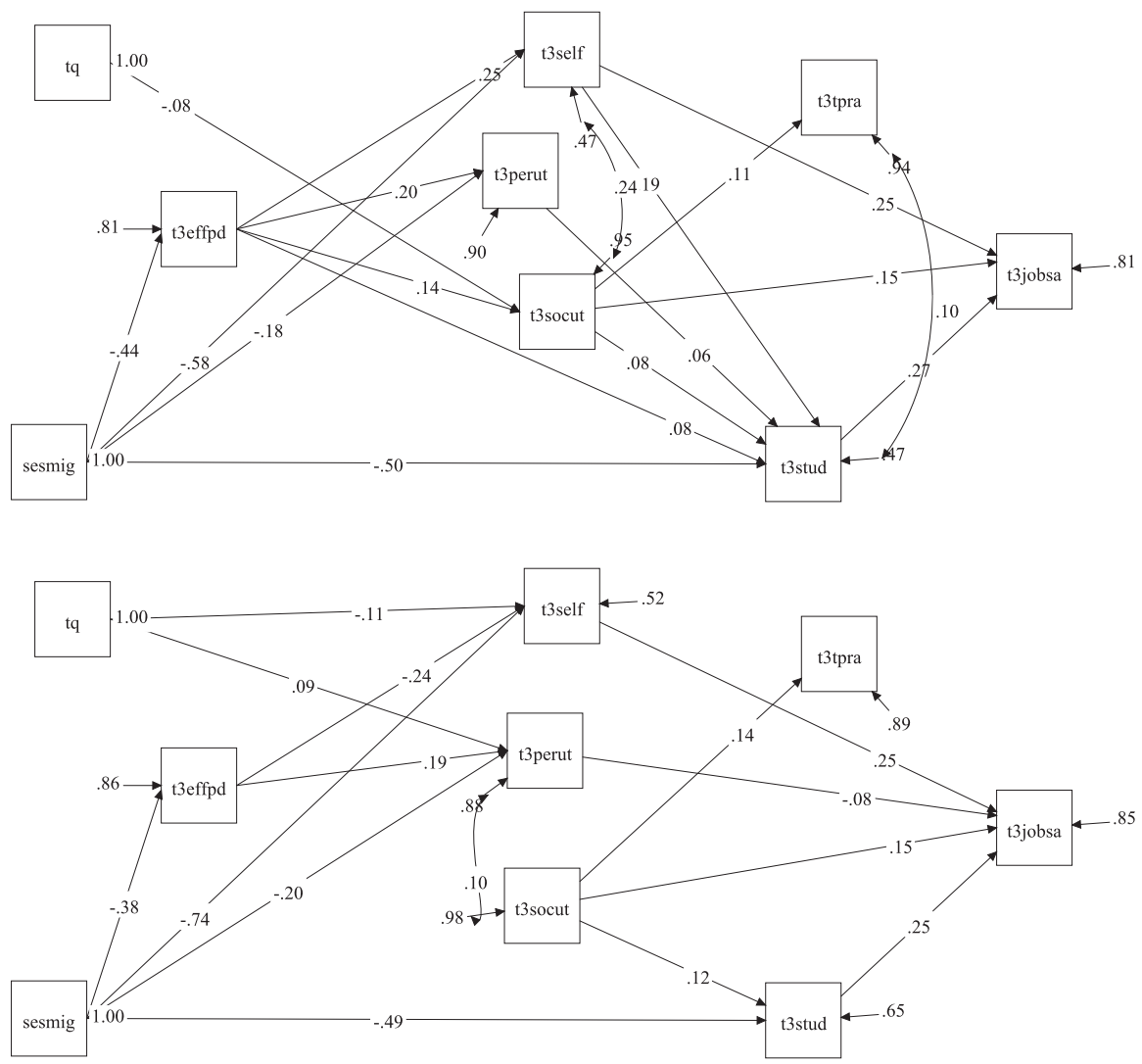

Fig. 5.6 Path diagram for Finland (top) and Denmark (down) in TALIS 2018. (Note: T3EFFPD effective professional development, T3PERUT personal utility value, T3SOCUT social utility value, T3STUD teacher-student relations, T3TPRA teaching practices, T3JOBSA job satisfaction, T3SELF teacher self-efficacy, $T Q$ teacher qualification, SESMIG classroom students SES and migration background composition. Only significant paths are shown)

The analysis also revealed a total negative indirect effect of perceived disadvantaged classroom SES-ethnic composition (SESMIG) on teacher job satisfaction (T3JOBSA) by -0.36 . The most significant indirect effect of SESMIG on T3JOBSA was via the teachers' professional self-efficacy $(-0.15)$ and student-teacher relations (-0.14). Other indirect effects between the two (SESMIG on T3JOBSA) were via teacher practices (T3TPRA), teacher social utility motivation (T3SOCUT), effective professional development (T3EFFPD) and teacher-student relations (T3STUD). However, these indirect effects, despite their significance, were minimal. TQ was also observed to have small indirect effects on job satisfaction (T3JOBSA) through teacher-student relations (T3STUD) and their social utility motivation (T3SOCUT).

In Denmark, teachers' professional self-efficacy (T3SELF) and their relation with students (T3STUD) have a significant and positive direct impact on their job 
satisfaction, both being at 0.25 . Teachers' personal utility motivation to teach (T3PERUT) was found to have a small negative effect $(-0.08)$, while teachers' social utility motivation to teach (T3SOCUT) had a positive impact (0.15), almost twice as large as their personal utility motivation. No significant effects were found for teachers' effective professional development (T3EFFPD), teaching practices (T3TPRA), TQ and classroom disadvantaged SES-ethnic composition (SESMIG) on their job satisfaction (T3JOBSA).

Classroom socioeconomic and ethnic composition (SESMIG) affected most of the teacher-related factors negatively. The highest effect was found on teachers' professional self-efficacy $(-0.75)$, followed by the effect on teacher-student relations $(-0.49)$. The effects of the classroom socioeconomic and ethnic composition (SESMIG) on teachers' effective professional development (T3EFFPD) and teachers' personal utility motivation (T3PERUT) were -0.20 and -0.38 , respectively. The classroom socioeconomic and ethnic composition (SESMIG) also was found to have a significant indirect effect on teachers' job satisfaction $(-0.27)$.

A common feature revealed in the analysis of the TALIS 2018 data is the positive direct effects of teacher-student relations and teachers' social utility motivation to teach on job satisfaction in all the Nordic countries. Sweden held the most substantial impact of the teacher-student relationship on job satisfaction (0.42), and the effect of the rest of the Nordic countries was very similar, around 0.25 . The direct effect of social utility motivation, on the other hand, as about the same level in all the four Nordic countries, approximately 0.15 . We also found a positive impact of teachers' social utility motivation to teach on their teaching practices, with Norway and Sweden being higher than those of Denmark and Finland. Strong adverse effects were observed of the disadvantaged classroom SES-ethnic composition and teacher-student relations, ranging from -0.67 in Sweden to -0.41 in Norway and on teachers' effective professional development, ranging from -0.46 in Norway to -0.27 in Sweden. SESMIG significantly affected teacher's professional selfefficacy. However, the effect was highly negative in Norway, Denmark and Finland but positive in Sweden.

Diversities in the mechanisms, however, were also revealed in the analysis. For example, Swedish teacher's job satisfaction and effective professional development were affected positively by the disadvantaged classroom SES-ethnic composition. In contrast, teacher qualification affected their job satisfaction negatively. In Denmark, the teachers' effective professional development positively impacted their personal utility motivation and was negatively related to their professional self-efficacy. However, the opposite or no effect was found in other countries. Please see the supplementary material, appendices D-F for the detailed specification on all the direct, indirect and total effects.

Table 5.4 shows the explained variance for all the dependent variables in the model. For the outcome variable job satisfaction, the proposed mechanism in the model was not fully reflected in the operationalised model in TALIS 2018. On average, around $18 \%$ variance in job satisfaction was accounted for by the model in the Nordic countries. This may imply that additional factors and mechanisms need to be considered for in teachers' job satisfaction. The proposed model explained a large 
Table 5.4 Explained variance of all the endogenous variables in the path models of the four Nordic countries in TALIS 2018

\begin{tabular}{l|l|l|l|l|l|l|l|r}
\hline & Denmark & \multicolumn{2}{l|}{ Finland } & \multicolumn{2}{l|}{ Norway } & \multicolumn{2}{l}{ Sweden } \\
\hline Variables about teacher & $\mathrm{R}^{2}(\%)$ & $\mathrm{z}$ & $\mathrm{R}^{2}(\%)$ & $\mathrm{z}$ & $\mathrm{R}^{2}(\%)$ & $\mathrm{z}$ & $\mathrm{R}^{2}(\%)$ & $\mathrm{z}$ \\
\hline Job satisfaction & 15 & 2.35 & 19 & 4.73 & 18 & 2.64 & 19 & 4.22 \\
\hline Teacher-student relations & 35 & 3.20 & 54 & 8.95 & 51 & 8.48 & 52 & 10.79 \\
\hline Teacher's self-efficacy & 48 & 3.19 & 53 & 8.57 & 63 & 8.73 & 12 & 1.06 \\
\hline Personal utility motivation to teach & 12 & 2.75 & 11 & 2.17 & 7 & 2.59 & 15 & 2.77 \\
\hline Social utility motivation to teach & 2 & 0.69 & 5 & 1.98 & 2 & 1.48 & 10 & 1.85 \\
\hline Effective professional development & 14 & 1.40 & 19 & 2.75 & 21 & 3.75 & 8 & 1.27 \\
\hline Teaching practices & 11 & 1.21 & 6 & 2.21 & 8 & 1.69 & 13 & 2.53 \\
\hline
\end{tabular}

amount of the variance in teachers' professional self-efficacy in Norway (63\%), Finland (54\%) and Denmark (48\%). However, in Sweden, only $12 \%$ of the differences can be attributed to the factors in the model, which was not significant. The same pattern, but to a much less extent, was found for teacher's effective professional development. Here, the amount of explained variance in Denmark and Sweden was not significant. The model explained a significant amount of the variances in all teacher-related variables in Finland. For the explained variance in teacher's social utility motivation to teach and teaching practices, Denmark and Norway had a small and nonsignificant amount.

Comparing the results from TALIS 2013 and 2018, the single factor that consistently affects teachers' job satisfaction is teacher-student relations. This effect is the largest in all four Nordic countries and TALIS cycles. However, teacher-student relations was significantly related to classroom SES-ethnic composition and teachers' professional self-efficacy. Furthermore, the TALIS 2013 analysis revealed the importance of teachers' professional self-efficacy for most of the other teacherrelated factors in all Nordic countries. However, this is not the case in TALIS 2018. The hypothesised model seems to be proved as true by the TALIS 2013 data in all the four Nordic countries, yet it worked less well for the TALIS 2018 data, especially for Denmark and Sweden.

\subsubsection{Discussion}

The idea of teacher quality and how teachers matter to students' well-being and outcomes has provoked a mass investigation that has spread over several decades and across disciplines. Although no unified definitions have been found, the concept of teacher quality embraces teachers' qualification, characteristics and the practices of teaching (Goe, 2007). Over the years, different aspects of teacher quality have been investigated, showing mutual interdependence (e.g., Liu \& Verblow, 2019; Fischer et al., 2018; Zee \& Koomen, 2016; Wang et al., 2019) and a link with student learning and outcomes (e.g., Caprara et al., 2006; Nye et al., 2004; Zee \& 
Koomen, 2016) and job satisfaction (e.g. Caprara et al., 2003; Vieluf et al., 2013). The latter has especially come to the fore in an era when retaining quality teachers has become challenging when teachers are met with more and more demands to adapt their own teaching relative to the needs of students with diverse social or migration backgrounds (Banerjee et al., 2017; Dicke et al., 2020). With this in mind, we investigated how the different aspects of teacher quality contribute to job satisfaction in connection to varied school environments relative to student composition and outcomes. In particular, we examined whether the mechanisms hold across the Nordic countries and if the same patterns are consistent over time (Reimer, 2019).

The comparative stance represented an essential facet of the current study. Analysing four Nordic countries has allowed us to observe systems in which the schools ought to be inclusive and comprehensive, while the teachers are seen as essential contributors in providing equal opportunities to all children (Blossing et al., 2014; Imsen et al., 2017; Lundahl, 2016). Thus, teacher quality is understood as instrumental in balancing equity across the education system. However, over the last two decades, even in the Nordic countries, an influx of accountability measures and marketing practices has introduced some changes, influencing how teachers view their profession and job satisfaction (Reimer, 2019; Taajamo, 2016). Capturing these factors were our focus.

Across the countries, we have observed that both uniform and diverse patterns were found relative to the relationship between teacher quality and job satisfaction. Comparing the results from TALIS 2013 and 2018, the single factor that consistently affects teachers' job satisfaction was the teacher-student relations. The effect on this was the largest in all four Nordic countries and both TALIS cycles. Prior research has also indicated relevant links between job satisfaction and the overall teacher-student relationship (Collie et al., 2012; Gil-Flores, 2017; Veldman et al., 2013).

Conversely, in the results related to the TALIS 2013 data, the factor teacher-student relations was significantly associated with classroom SES-ethnic composition and teachers' professional self-efficacy. The former has been reported in several studies, that is, a decrease in job satisfaction is affected by an increasing proportion of students from socioeconomically disadvantaged homes (Matsuoka, 2015; Wang et al., 2019). Schwab (2019) has also demonstrated how general self-efficacy is valuable in understanding the teacher-student relations: the higher the teachers' general self-efficacy is, the higher their student-specific self-efficacy will be. The latter, as Schwab reported, was lower for students from the special needs spectrum (i.e., learning, behavioural and emotional disorders). TALIS 2018 data also indicate that job satisfaction and teacher-student relations are highly affected by disadvantaged classroom academic environment. Given that job satisfaction is directly associated with occupational well-being, motivation and staying in the profession (Dicke et al., 2020), it is critical to provide the teachers with support in addressing the diversity they come across in the classrooms in a more sustained manner.

In all the Nordic countries, the analysis of TALIS 2013 data revealed the importance of teachers' self-efficacy for their collaboration activities with other teachers and their behaviour and attitude towards their students' learning and well-being. In 
turn, these factors together effectively affect teachers' job satisfaction. The finding very much links to a plethora of research on the importance of self-efficacy for teachers' professional practices and commitment to the profession (Chesnut \& Burley, 2015; Vieluf et al., 2013; Zee \& Koomen, 2016). Even though no student outcome was included in TALIS, it has been shown that these chained effects can enhance students' academic performance (e.g., Bandura, 1977; Klassen \& Tze, 2014). However, the pattern was only partially confirmed in the TALIS 2018 analysis. One explanation for this absence could be in the data 'unavailability'; that is, the two teacher-related factors in the TALIS 2013 model (i.e., teacher's constructivist beliefs and teacher collaboration) are absent from the TALIS 2018 models. These scales were replaced by teacher's personal and social utility motivation to teach and teaching practices. Another reason may be the somewhat lower explanatory power of the TALIS 2018 model. The correlation between classroom SES-ethnic composition and classroom academic environment was exceptionally high, leading to the exclusion of the classroom academic environment construct to avoid multicollinearity issues. Consequently, the model structure of the two TALIS cycles was not identical, and the estimation and interpretation of the interrelationships among the factors estimated from the model might be differentiated.

Although our results provide corroborating evidence in support of studentteacher relations or self-efficacy as affecting teachers' job satisfaction, diversities were also observed across the Nordic countries. The result patterns from the TALIS 2013 model outlined two subgroups of Nordic countries with similar mechanisms: the Norway-Sweden group and the Denmark-Finland group. This distinction is lost in the 2018 results, leading to more diverging and country-specific patterns, such as the importance of social utility value for Norway, adverse classroom composition in Sweden or teachers' effective professional development positively impacting personal and the social utility values of teachers in Finland. These observed diversities and changing patterns may be because of the gradually dissolved unity of the Nordic model by different reform actions taken in recent years, such as in Sweden (Lundahl, 2016), as well as in the long-term prerequisites for the teaching profession, where Finland stands out (Aspfors et al., 2014).

\subsubsection{Limitation and Further Research}

The nature of the data used in the current study holds both advantages and disadvantages. Although the data provide solid grounds for a comparative perspective, the data are cross-sectional. This means that even when observing information from different cycles, that is, 2013 and 2018, we cannot consider this to be a longitudinal investigation because different teachers within a country partake in each cycle. Nonetheless, the data do allow for conclusions on trends or a lack of these on established relationships within and across countries.

Second, with each TALIS cycle, a more robust data set has been built, offering more and more varied scales on the different aspects of teacher quality. With this in 
mind, some of the constructs used in the presented models are there in both the 2013 and 2018 data, while few were novel to the 2018 cycle (e.g., personal utility value). Although the use of the same variables in the 2013 and 2018 models would offer opportunities for a direct comparison between the models, we opted for a more comprehensive view that would not limit our investigation merely to the constructs available in both cycles. Our assumption was that the approach would allow for a more nuanced view of the essential mechanisms contributing to teachers' job satisfaction.

In this round of our investigation, we opted for one-level models. We were guided by the idea that such an approach would foster more focused studies at a later stage that could involve the exploration of school-level factors pertinent to the particular direct and indirect effects established in this step. The results for the outcome variable in the operationalised model in TALIS 2018 (e.g., around 18\% variance in job satisfaction being accounted for by the model in the Nordic countries) support this line of thinking.

\subsection{Conclusions}

In this chapter, we have investigated how the different aspects of teacher quality may affect job satisfaction, here in connection to diverse school environments relative to student composition and outcomes. The extent that the determined mechanisms apply across the Nordic countries and if the same patterns are consistent over different time points became the second focus of the study. Although common values are shared across the Nordic arena (Blossing et al., 2014; Imsen et al., 2017; Lundahl, 2016) and some of these are mirrored in the results of the current study (i.e., patterns in 2013 data), these also point to some diverse practices and ideas pertinent to individual countries (e.g., Aspfors et al., 2014; Wollscheid \& Opheim, 2016). The latter are especially noticeable in the observed mechanism for 2018 , indicating the presence of more diversified practices across the Nordic countries. Although equity and quality are still the common goals that these countries are striving to achieve, the mechanisms through which each education system approaches these goals have become more diverse. Both the changing patterns and differences could originate in the steadily dissolved unity of the Nordic model, here affected by the different reform actions taken in recent years. Sweden is a clear example of the latter with its extensive decentralisation and deregulation reforms, while Finland stands out with its long-term prerequisites for the teaching profession. The current evidence (i.e., the importance of social utility value for Norway, adverse classroom composition in Sweden or teacher effective professional development positively impacting personal and social utility values of teachers in Finland) warrants a continuation of the investigation into these distinctive patterns, with the possible inclusion of additional factors and mechanisms from the school level. 


\section{Appendices}

\section{Appendix A: Standardized Direct Effects Among Variable in the Path Analysis for the Four Nordic Countries in TALIS 2013}

\begin{tabular}{|c|c|c|c|c|c|c|c|c|}
\hline & \multicolumn{2}{|l|}{ Denmark } & \multicolumn{2}{|l|}{ Finland } & \multicolumn{2}{|l|}{ Norway } & \multicolumn{2}{|l|}{ Sweden } \\
\hline & Estimate & $\mathrm{Z}$ & Estimate & Z & Estimate & $\mathrm{Z}$ & Estimate & $\mathrm{Z}$ \\
\hline $\begin{array}{l}\text { TJOBSATS } \\
\text { ON } \\
\text { TSELEFFS }\end{array}$ & .19 & 7.04 & .20 & 8.45 & .16 & 6.88 & .15 & 7.76 \\
\hline $\begin{array}{l}\text { TJOBSATS } \\
\text { ON } \\
\text { TEFFPROS }\end{array}$ & .01 & .48 & .03 & 1.21 & .08 & 3.68 & .09 & 3.81 \\
\hline $\begin{array}{l}\text { TJOBSATS } \\
\text { ON TCONSBS }\end{array}$ & .03 & 1.01 & .00 & -.18 & .06 & 2.13 & .05 & 2.49 \\
\hline $\begin{array}{l}\text { TJOBSATS } \\
\text { ON TCCOLLS }\end{array}$ & .07 & 2.80 & .07 & 3.58 & .13 & 6.11 & .15 & 7.86 \\
\hline $\begin{array}{l}\text { TJOBSATS } \\
\text { ON } \\
\text { TSCTSTUDS }\end{array}$ & .28 & 11.49 & .32 & 14.69 & .31 & 12.46 & .19 & 10.10 \\
\hline $\begin{array}{l}\text { TJOBSATS } \\
\text { ON TQ }\end{array}$ & -.06 & -3.29 & -.02 & -.85 & -.04 & -1.56 & -.07 & -4.19 \\
\hline $\begin{array}{l}\text { TJOBSATS } \\
\text { ON SESMIG }\end{array}$ & -.04 & -1.17 & -.07 & -3.09 & -.04 & -1.84 & -.07 & -2.65 \\
\hline $\begin{array}{l}\text { TJOBSATS } \\
\text { ON } \\
\text { CLACDEN }\end{array}$ & -.12 & -3.63 & -.05 & -2.14 & -.06 & -2.23 & -.04 & -1.79 \\
\hline $\begin{array}{l}\text { TCCOLLS ON } \\
\text { TSELEFFS }\end{array}$ & .16 & 5.53 & .18 & 8.48 & .20 & 5.31 & .17 & 7.60 \\
\hline $\begin{array}{l}\text { TCCOLLS ON } \\
\text { TCONSBS }\end{array}$ & .03 & 1.15 & .03 & 1.35 & -.04 & -1.28 & .05 & 2.08 \\
\hline $\begin{array}{l}\text { TCCOLLS ON } \\
\text { TEFFPROS }\end{array}$ & .13 & 4.28 & .18 & 7.70 & .19 & 5.32 & .23 & 10.35 \\
\hline $\begin{array}{l}\text { TCCOLLS ON } \\
\text { TQ }\end{array}$ & .00 & .11 & -.03 & -1.40 & .03 & 1.23 & .04 & 1.54 \\
\hline $\begin{array}{l}\text { TCCOLLS ON } \\
\text { SESMIG }\end{array}$ & .02 & .55 & .11 & 3.10 & -.01 & -.30 & .04 & 1.46 \\
\hline $\begin{array}{l}\text { TCCOLLS ON } \\
\text { CLACDEN }\end{array}$ & .23 & 5.32 & .17 & 6.73 & .12 & 3.45 & .14 & 6.44 \\
\hline $\begin{array}{l}\text { TSCTSTUD } \\
\text { ON } \\
\text { TSELEFFS }\end{array}$ & .17 & 6.46 & .23 & 10.28 & .21 & 6.56 & .21 & 10.34 \\
\hline $\begin{array}{l}\text { TSCTSTUD } \\
\text { ON TCONSBS }\end{array}$ & .15 & 4.83 & .03 & 1.46 & .08 & 2.79 & .05 & 1.92 \\
\hline
\end{tabular}




\begin{tabular}{|c|c|c|c|c|c|c|c|c|}
\hline & \multicolumn{2}{|l|}{ Denmark } & \multicolumn{2}{|l|}{ Finland } & \multicolumn{2}{|l|}{ Norway } & \multicolumn{2}{|l|}{ Sweden } \\
\hline & Estimate & $\mathrm{Z}$ & Estimate & Z & Estimate & Z & Estimate & $Z$ \\
\hline $\begin{array}{l}\text { TSCTSTUD } \\
\text { ON } \\
\text { TEFFPROS }\end{array}$ & .13 & 4.65 & .05 & 1.65 & .12 & 3.52 & .06 & 2.28 \\
\hline $\begin{array}{l}\text { TSCTSTUD } \\
\text { ON TQ }\end{array}$ & -.04 & -1.87 & .03 & 1.11 & .01 & .42 & .02 & .88 \\
\hline $\begin{array}{l}\text { TSCTSTUD } \\
\text { ON SESMIG }\end{array}$ & -.13 & -3.82 & -.05 & -2.00 & -.05 & -1.98 & -.06 & -2.15 \\
\hline $\begin{array}{l}\text { TSCTSTUD } \\
\text { ON } \\
\text { CLACDEN }\end{array}$ & -.04 & -1.13 & -.12 & -4.47 & .00 & -.15 & -.09 & -3.24 \\
\hline $\begin{array}{l}\text { TSELEFFS } \\
\text { ON } \\
\text { TEFFPROS }\end{array}$ & .07 & 2.24 & .12 & 5.62 & .07 & 2.82 & .08 & 3.59 \\
\hline $\begin{array}{l}\text { TSELEFFS } \\
\text { ON TQ }\end{array}$ & .12 & 4.16 & .03 & 1.40 & .06 & 1.79 & .04 & 1.93 \\
\hline $\begin{array}{l}\text { TSELEFFS } \\
\text { ON SESMIG }\end{array}$ & -.05 & -1.37 & .08 & 3.05 & .11 & 4.19 & .02 & 1.08 \\
\hline $\begin{array}{l}\text { TSELEFFS } \\
\text { ON } \\
\text { CLACDEN }\end{array}$ & -.12 & -3.35 & .04 & 1.80 & -.13 & -5.32 & -.02 & -1.00 \\
\hline $\begin{array}{l}\text { TCONSBS ON } \\
\text { TEFFPROS }\end{array}$ & .09 & 2.79 & .10 & 4.41 & .04 & 1.37 & .04 & 1.72 \\
\hline $\begin{array}{l}\text { TCONSBS ON } \\
\text { TQ }\end{array}$ & .03 & .95 & .04 & 1.57 & -.02 & -.59 & -.05 & -2.03 \\
\hline $\begin{array}{l}\text { TCONSBS ON } \\
\text { SESMIG }\end{array}$ & .09 & 3.13 & .02 & 1.03 & .02 & .79 & .03 & 1.16 \\
\hline $\begin{array}{l}\text { TCONSBS ON } \\
\text { CLACDEN }\end{array}$ & -.13 & -3.68 & .03 & 1.40 & -.05 & -1.58 & -.01 & -.30 \\
\hline $\begin{array}{l}\text { TEFFPROS } \\
\text { ON TQ }\end{array}$ & -.01 & -.49 & .04 & 1.64 & .00 & -.10 & .03 & 1.46 \\
\hline $\begin{array}{l}\text { TEFFPROS } \\
\text { ON SESMIG }\end{array}$ & .04 & .88 & .04 & 1.21 & .02 & .54 & .00 & .13 \\
\hline $\begin{array}{l}\text { TEFFPROS } \\
\text { ON } \\
\text { CLACDEN }\end{array}$ & -.09 & -2.14 & -.06 & -2.18 & .01 & .44 & .00 & -.11 \\
\hline
\end{tabular}




\section{Appendix B: Standardized Total Direct and Indirect Effects Among Variable in the Path Analysis for the Four Nordic Countries in TALIS 2013}

\begin{tabular}{|c|c|c|c|c|c|c|c|c|}
\hline \multirow[b]{2}{*}{ Effects from TQ to TJOBSATS } & \multicolumn{2}{|c|}{ Danmark } & \multicolumn{2}{|c|}{ Finland } & \multicolumn{2}{|c|}{ Norway } & \multicolumn{2}{|c|}{ Sweden } \\
\hline & est. & $\mathrm{z}$ & est. & $\mathrm{z}$ & est. & $\mathrm{z}$ & est. & $\mathrm{z}$ \\
\hline Total & -.04 & -1.63 & .00 & .21 & -.02 & -.79 & -.05 & -2.79 \\
\hline Direct & -.06 & -3.29 & -.02 & -.85 & -.04 & -1.56 & -.07 & -4.19 \\
\hline Total indirect & .02 & 1.559 & .02 & 1.90 & .02 & 1.29 & .02 & 2.09 \\
\hline Effects from SESMIG & est. & $\mathrm{z}$ & est. & $\mathrm{z}$ & est. & $\mathrm{z}$ & est. & $\mathrm{z}$ \\
\hline Total & -.08 & -2.13 & -.05 & -1.98 & -.02 & -1.07 & -.07 & -2.33 \\
\hline Direct & -.04 & -1.17 & -.07 & -3.09 & -.04 & -1.84 & -.07 & -2.65 \\
\hline Total indirect & -.04 & -2.34 & .02 & 1.43 & .02 & 1.18 & .00 & .18 \\
\hline Effects from CLACDEN & est. & $\mathrm{z}$ & est. & $\mathrm{z}$ & est. & $\mathrm{z}$ & est. & $\mathrm{z}$ \\
\hline Total & -.16 & -4.43 & -.07 & -2.74 & -.08 & -2.69 & -.04 & -1.68 \\
\hline Direct & -.12 & -3.63 & -.05 & -2.14 & -.06 & -2.23 & -.04 & -1.79 \\
\hline Total indirect & -.04 & -2.62 & -.02 & -1.50 & -.02 & -1.35 & .00 & .04 \\
\hline Effects from TEFFPRO & est. & $\mathrm{z}$ & est. & $\mathrm{z}$ & est. & $\mathrm{z}$ & est. & $\mathrm{z}$ \\
\hline Total & .08 & 2.69 & .09 & 3.59 & .16 & 5.32 & .15 & 6.34 \\
\hline Direct & .01 & 0.48 & .03 & 1.21 & .08 & 3.68 & .09 & 3.81 \\
\hline Total indirect & .07 & 5.22 & .06 & 4.63 & .08 & 5.03 & .07 & 7.04 \\
\hline Effects from TSELEFF & est. & $\mathrm{z}$ & est. & $\mathrm{z}$ & est. & $\mathrm{z}$ & est. & $\mathrm{z}$ \\
\hline Total & .24 & 8.85 & .29 & 12.46 & .25 & 9.05 & .21 & 11.01 \\
\hline Direct & .19 & 7.04 & .20 & 8.45 & .16 & 6.88 & .15 & 7.76 \\
\hline Total indirect & .06 & 5.93 & .09 & 9.44 & .089 & 8.09 & .07 & 9.95 \\
\hline Effects from TCONSBS & est. & $\mathrm{z}$ & est. & $\mathrm{z}$ & est. & $\mathrm{z}$ & est. & $\mathrm{z}$ \\
\hline Total & .07 & 2.60 & .01 & .45 & .08 & 3.17 & .07 & 3.31 \\
\hline Direct & .025 & 1.010 & -.00 & -.18 & .06 & 2.13 & .05 & 2.49 \\
\hline Total indirect & .044 & 4.342 & .01 & 1.65 & .02 & 1.78 & .02 & 2.39 \\
\hline
\end{tabular}

\section{Appendix C: Detailed Indirect Effect in the Operationalized Model in All Four Nordic Countries in TALIS 2013}

\begin{tabular}{l|l|l|l|l|l|l|l|l|l|}
\hline & \multicolumn{3}{|l|}{ Denmark } & \multicolumn{2}{l|}{ Finland } & \multicolumn{2}{l|}{ Norway } & \multicolumn{2}{l}{ Sweden } \\
\hline & est & $\mathrm{z}$ & est & $\mathrm{z}$ & est & $\mathrm{z}$ & est & $\mathrm{z}$ \\
\hline TQ on TSELEFFS on TJOBSATS & $\mathbf{. 0 2}$ & $\mathbf{3 . 4 5}$ & .01 & 1.35 & .01 & 1.82 & .01 & 1.87 \\
\hline TQ on TSCTSTUD on TJOBSATS & -.01 & -1.82 & .01 & 1.10 & .00 & .42 & .00 & .89 \\
\hline TQ on TCONSBS on TJOBSATS & .00 & .67 & .00 & -.18 & .00 & -.59 & .00 & -1.51 \\
\hline TQ on TEFFPROS on TJOBSATS & .00 & -.34 & .00 & 1.02 & .00 & -.11 & .00 & 1.36 \\
\hline
\end{tabular}




\begin{tabular}{|c|c|c|c|c|c|c|c|c|}
\hline & \multicolumn{2}{|c|}{ Denmark } & \multicolumn{2}{|c|}{ Finland } & \multicolumn{2}{|c|}{ Norway } & \multicolumn{2}{|c|}{ Sweden } \\
\hline & est & $\mathrm{z}$ & est & $\mathrm{z}$ & est & $\mathrm{z}$ & est & $\mathrm{z}$ \\
\hline TQ on TCCOLLS on TJOBSATS & .00 & .11 & .00 & -1.33 & .00 & 1.23 & .01 & 1.58 \\
\hline $\begin{array}{l}\text { TQ on TEFFPROS on TSELEFFS } \\
\text { on TJOBSATS }\end{array}$ & .00 & -.47 & .00 & 1.56 & .00 & -.11 & .00 & 1.39 \\
\hline $\begin{array}{l}\text { TQ on TSELEFFS on TSCTSTUD } \\
\text { on TJOBSATS }\end{array}$ & .01 & 3.51 & .00 & 1.37 & .00 & 1.72 & .00 & 1.82 \\
\hline $\begin{array}{l}\text { TQ on TCONSBS on TSCTSTUD } \\
\text { on TJOBSATS }\end{array}$ & .00 & .95 & .00 & 1.06 & .00 & -.54 & .00 & -1.50 \\
\hline $\begin{array}{l}\text { TQ on TEFFPROS on TSCTSTUD } \\
\text { on TJOBSATS }\end{array}$ & .00 & -.48 & .00 & 1.11 & .00 & -.11 & .00 & 1.12 \\
\hline $\begin{array}{l}\text { TQ on TEFFPROS on TCONSBS } \\
\text { on TJOBSATS }\end{array}$ & .00 & -.42 & .00 & -.18 & .00 & -.10 & .00 & 1.08 \\
\hline $\begin{array}{l}\text { TQ on TSELEFFS on TCCOLLS } \\
\text { on TJOBSATS }\end{array}$ & .00 & 2.37 & .00 & 1.31 & .00 & 1.70 & .00 & 1.86 \\
\hline $\begin{array}{l}\text { TQ on TCONSBS on TCCOLLS } \\
\text { on TJOBSATS }\end{array}$ & .00 & .83 & .00 & 1.00 & .00 & .54 & .00 & -1.58 \\
\hline $\begin{array}{l}\text { TQ on TEFFPROS on TCCOLLS } \\
\text { on TJOBSATS }\end{array}$ & .00 & -.48 & .00 & 1.50 & .00 & -.10 & .00 & 1.42 \\
\hline $\begin{array}{l}\text { TQ on TEFFPROS on TSELEFFS } \\
\text { on TSCTSTUD on TJOBSATS }\end{array}$ & .00 & -.47 & .00 & 1.59 & .00 & -.11 & .00 & 1.38 \\
\hline $\begin{array}{l}\text { TQ on TEFFPROS on TCONSBS } \\
\text { on TSCTSTUD on TJOBSATS }\end{array}$ & .00 & -.49 & .00 & 1.02 & .00 & -.10 & .00 & .91 \\
\hline $\begin{array}{l}\text { TQ on TEFFPROS on TSELEFFS } \\
\text { on TCCOLLS on TJOBSATS }\end{array}$ & .00 & -.47 & .00 & 1.46 & .00 & -.11 & .00 & 1.32 \\
\hline $\begin{array}{l}\text { TQ on TEFFPROS on TCONSBS } \\
\text { on TCCOLLS on TJOBSATS }\end{array}$ & .00 & -.43 & .00 & .92 & .00 & .10 & .00 & 1.00 \\
\hline $\begin{array}{l}\text { SESMIG on TSELEFFS on } \\
\text { TJOBSATS }\end{array}$ & -.01 & -1.28 & .02 & 2.98 & .02 & 3.73 & .00 & 1.09 \\
\hline $\begin{array}{l}\text { SESMIG on TSCTSTUD on } \\
\text { TJOBSATS }\end{array}$ & -.04 & -3.53 & -.02 & -1.96 & -.02 & -1.91 & -.01 & -2.12 \\
\hline $\begin{array}{l}\text { SESMIG on TCONSBS on } \\
\text { TJOBSATS }\end{array}$ & .00 & .96 & .00 & -.18 & .00 & .71 & .00 & 1.07 \\
\hline $\begin{array}{l}\text { SESMIG on TEFFPROS on } \\
\text { TJOBSATS }\end{array}$ & .00 & .49 & .00 & .93 & .00 & .52 & .00 & .13 \\
\hline $\begin{array}{l}\text { SESMIG on TCCOLLS on } \\
\text { TJOBSATS }\end{array}$ & .00 & .53 & .01 & 2.21 & .00 & -.30 & .01 & 1.42 \\
\hline $\begin{array}{l}\text { SESMIG on TEFFPROS on } \\
\text { TSELEFFS on TJOBSATS }\end{array}$ & .00 & .83 & .00 & 1.14 & .00 & .51 & .00 & .13 \\
\hline $\begin{array}{l}\text { SESMIG on TSELEFFS on } \\
\text { TSCTSTUD on TJOBSATS }\end{array}$ & .00 & -1.33 & .01 & 2.89 & .01 & 3.74 & .00 & 1.05 \\
\hline $\begin{array}{l}\text { SESMIG on TCONSBS on } \\
\text { TSCTSTUD on TJOBSATS }\end{array}$ & .00 & 2.63 & .00 & .84 & .00 & .80 & .00 & .96 \\
\hline $\begin{array}{l}\text { SESMIG on TEFFPROS on } \\
\text { TSCTSTUD on TJOBSATS }\end{array}$ & .00 & .88 & .00 & 1.02 & .00 & .52 & .00 & .13 \\
\hline $\begin{array}{l}\text { SESMIG on TEFFPROS on } \\
\text { TCONSBS on TJOBSATS }\end{array}$ & .00 & .64 & .00 & -.18 & .00 & .50 & .00 & .13 \\
\hline
\end{tabular}




\begin{tabular}{|c|c|c|c|c|c|c|c|c|}
\hline & \multicolumn{2}{|c|}{ Denmark } & \multicolumn{2}{|c|}{ Finland } & \multicolumn{2}{|c|}{ Norway } & \multicolumn{2}{|c|}{ Sweden } \\
\hline & est & $\mathrm{z}$ & est & $\mathrm{z}$ & est & $\mathrm{z}$ & est & $\mathrm{z}$ \\
\hline $\begin{array}{l}\text { SESMIG on TSELEFFS on } \\
\text { TCCOLLS on TJOBSATS }\end{array}$ & .00 & -1.28 & .00 & 2.17 & .00 & 3.09 & .00 & 1.05 \\
\hline $\begin{array}{l}\text { SESMIG on TCONSBS on } \\
\text { TCCOLLS on TJOBSATS }\end{array}$ & .00 & .98 & .00 & .79 & .00 & -.59 & .00 & 1.01 \\
\hline $\begin{array}{l}\text { SESMIG on TEFFPROS on } \\
\text { TCCOLLS on TJOBSATS }\end{array}$ & .00 & .85 & .00 & 1.09 & .00 & .53 & .00 & .13 \\
\hline $\begin{array}{l}\text { SESMIG on TEFFPROS on } \\
\text { TSELEFFS on TSCTSTUD on } \\
\text { TJOBSATS }\end{array}$ & .00 & .83 & .00 & 1.13 & .00 & .50 & .00 & .13 \\
\hline $\begin{array}{l}\text { SESMIG on TEFFPROS on } \\
\text { TCONSBS on TSCTSTUD on } \\
\text { TJOBSATS }\end{array}$ & .00 & .82 & .00 & .94 & .00 & .46 & .00 & .13 \\
\hline $\begin{array}{l}\text { SESMIG on TEFFPROS on } \\
\text { TSELEFFS on TCCOLLS on } \\
\text { TJOBSATS }\end{array}$ & .00 & .82 & .00 & 1.08 & .00 & .50 & .00 & .14 \\
\hline $\begin{array}{l}\text { SESMIG on TEFFPROS on } \\
\text { TCONSBS on TCCOLLS on } \\
\text { TJOBSATS }\end{array}$ & .00 & .70 & .00 & .81 & .00 & -.46 & .00 & .13 \\
\hline $\begin{array}{l}\text { CLACDEN on TSELEFFS on } \\
\text { TJOBSATS }\end{array}$ & -.02 & -3.33 & .01 & 1.74 & -.02 & -4.07 & .00 & -1.00 \\
\hline $\begin{array}{l}\text { CLACDEN on TSCTSTUD on } \\
\text { TJOBSATS }\end{array}$ & -.01 & -1.14 & -.04 & -4.14 & .00 & -.15 & -.02 & -3.12 \\
\hline $\begin{array}{l}\text { CLACDEN on TCONSBS on } \\
\text { TJOBSATS }\end{array}$ & .00 & -1.00 & .00 & -.18 & .00 & -1.27 & .00 & -.30 \\
\hline $\begin{array}{l}\text { CLACDEN on TEFFPROS on } \\
\text { TJOBSATS }\end{array}$ & .00 & -.49 & .00 & -.99 & .00 & .43 & .00 & -.11 \\
\hline $\begin{array}{l}\text { CLACDEN on TCCOLLS on } \\
\text { TJOBSATS }\end{array}$ & .02 & 2.85 & .01 & 3.27 & .02 & 3.11 & .02 & 5.32 \\
\hline $\begin{array}{l}\text { CLACDEN on TEFFPROS on } \\
\text { TSELEFFS on TJOBSATS }\end{array}$ & .00 & -1.42 & .00 & -1.86 & .00 & .42 & .00 & -.11 \\
\hline $\begin{array}{l}\text { CLACDEN on TSELEFFS on } \\
\text { TSCTSTUD on TJOBSATS }\end{array}$ & -.01 & -3.01 & .00 & 1.79 & -.01 & -3.75 & .00 & -.98 \\
\hline $\begin{array}{l}\text { CLACDEN on TCONSBS on } \\
\text { TSCTSTUD on TJOBSATS }\end{array}$ & -.01 & -2.75 & .00 & 1.00 & .00 & -1.30 & .00 & -.29 \\
\hline $\begin{array}{l}\text { CLACDEN on TEFFPROS on } \\
\text { TSCTSTUD on TJOBSATS }\end{array}$ & .00 & -2.09 & .00 & -1.42 & .00 & .44 & .00 & -.11 \\
\hline $\begin{array}{l}\text { CLACDEN on TEFFPROS on } \\
\text { TCONSBS on TJOBSATS }\end{array}$ & .00 & -.94 & .00 & .18 & .00 & .42 & .00 & -.11 \\
\hline $\begin{array}{l}\text { CLACDEN on TSELEFFS on } \\
\text { TCCOLLS on TJOBSATS }\end{array}$ & .00 & -2.08 & .00 & 1.53 & .00 & -2.76 & .00 & -.97 \\
\hline $\begin{array}{l}\text { CLACDEN on TCONSBS on } \\
\text { TCCOLLS on TJOBSATS }\end{array}$ & .00 & -1.06 & .00 & 1.04 & .00 & .90 & .00 & -.29 \\
\hline $\begin{array}{l}\text { CLACDEN on TEFFPROS on } \\
\text { TCCOLLS on TJOBSATS }\end{array}$ & .00 & -1.86 & .00 & -1.83 & .00 & .43 & .00 & -.11 \\
\hline $\begin{array}{l}\text { CLACDEN on TEFFPROS on } \\
\text { TSELEFFS on TSCTSTUD on } \\
\text { TJOBSATS }\end{array}$ & .00 & -1.44 & .00 & -1.91 & .00 & .44 & .00 & -.11 \\
\hline
\end{tabular}




\begin{tabular}{|c|c|c|c|c|c|c|c|c|}
\hline & \multicolumn{2}{|c|}{ Denmark } & \multicolumn{2}{|c|}{ Finland } & \multicolumn{2}{|c|}{ Norway } & \multicolumn{2}{|c|}{ Sweden } \\
\hline & est & $\mathrm{z}$ & est & $\mathrm{z}$ & est & $\mathrm{z}$ & est & $\mathrm{z}$ \\
\hline $\begin{array}{l}\text { CLACDEN on TEFFPROS on } \\
\text { TCONSBS on TSCTSTUD on } \\
\text { TJOBSATS }\end{array}$ & .00 & -1.49 & .00 & -1.15 & .00 & .44 & .00 & -.11 \\
\hline $\begin{array}{l}\text { CLACDEN on TEFFPROS on } \\
\text { TSELEFFS on TCCOLLS on } \\
\text { TJOBSATS }\end{array}$ & .00 & -1.42 & .00 & -1.65 & .00 & .42 & .00 & -.11 \\
\hline $\begin{array}{l}\text { CLACDEN on TEFFPROS on } \\
\text { TCONSBS on TCCOLLS on } \\
\text { TJOBSATS }\end{array}$ & .00 & -.92 & .00 & -.98 & .00 & -.39 & .00 & -.11 \\
\hline TEFFPROS on TSELEFFS on & .01 & 2.09 & .02 & 4.47 & .01 & 2.57 & .01 & .37 \\
\hline $\begin{array}{l}\text { TEFFPROS on TSCTSTUD on } \\
\text { TJOBSATS }\end{array}$ & .04 & 4.08 & .02 & 1.67 & .04 & 3.28 & .01 & 2.21 \\
\hline $\begin{array}{l}\text { TEFFPROS on TCONSBS on } \\
\text { TJOBSATS }\end{array}$ & .00 & 1.02 & .00 & -.18 & .00 & 1.25 & .00 & 1.42 \\
\hline $\begin{array}{l}\text { TEFFPROS on TCCOLLS on } \\
\text { TJOBSATS }\end{array}$ & .01 & 2.32 & .01 & 3.33 & .02 & 4.15 & .03 & 6.23 \\
\hline $\begin{array}{l}\text { TEFFPROS on TSELEFFS on } \\
\text { TSCTSTUD on TJOBSATS }\end{array}$ & .00 & 2.10 & .01 & 5.09 & .01 & 2.83 & .00 & 3.30 \\
\hline $\begin{array}{l}\text { TEFFPROS on TCONSBS on } \\
\text { TSCTSTUD on TJOBSATS }\end{array}$ & .00 & 2.79 & .00 & 1.41 & .00 & 1.16 & .00 & 1.16 \\
\hline $\begin{array}{l}\text { TEFFPROS on TSELEFFS on } \\
\text { TCCOLLS on TJOBSATS }\end{array}$ & .00 & 1.77 & .00 & 2.66 & .00 & 2.14 & .00 & 2.89 \\
\hline $\begin{array}{l}\text { TEFFPROS on TCONSBS on } \\
\text { TCCOLLS on TJOBSATS }\end{array}$ & .00 & 1.05 & .00 & 1.17 & .00 & -.91 & .00 & 1.26 \\
\hline $\begin{array}{l}\text { TSELEFFS-TSCTSTUD on } \\
\text { TJOBSATS }\end{array}$ & .05 & 5.50 & .07 & 8.59 & .06 & 6.50 & .04 & 7.34 \\
\hline $\begin{array}{l}\text { TSELEFFS on TCCOLLS on } \\
\text { TJOBSATS }\end{array}$ & .01 & 2.63 & .01 & 3.10 & .03 & 3.65 & .03 & 5.63 \\
\hline $\begin{array}{l}\text { TCONSBS-TSCTSTUD on } \\
\text { TJOBSATS }\end{array}$ & .04 & 4.39 & .01 & 1.44 & .03 & 2.87 & .01 & 1.89 \\
\hline $\begin{array}{l}\text { TCONSBS on TCCOLLS on } \\
\text { TJOBSATS }\end{array}$ & .00 & 1.09 & .00 & 1.27 & -.01 & -1.23 & .01 & 2.04 \\
\hline
\end{tabular}

\section{Appendix D: Standardized Direct Effects Among Variable in the Path Analysis for the Four Nordic Countries in TALIS 2018}

\begin{tabular}{|c|c|c|c|c|c|c|c|c|}
\hline & \multicolumn{2}{|c|}{ Denmark } & \multicolumn{2}{|c|}{ Finland } & \multicolumn{2}{|c|}{ Norway } & \multicolumn{2}{|c|}{ Sweden } \\
\hline & Est. & $\mathrm{z}$ & Est. & $\mathrm{z}$ & Est. & $\mathrm{z}$ & Est. & $\mathrm{z}$ \\
\hline T3JOBSA ON TQ & -.01 & -.36 & -.03 & -.87 & -.05 & -.65 & -.16 & -3.26 \\
\hline
\end{tabular}




\begin{tabular}{|c|c|c|c|c|c|c|c|c|}
\hline & \multicolumn{2}{|c|}{ Denmark } & \multicolumn{2}{|c|}{ Finland } & \multicolumn{2}{|c|}{ Norway } & \multicolumn{2}{|c|}{ Sweden } \\
\hline & Est. & $\mathrm{z}$ & Est. & $\mathrm{z}$ & Est. & $\mathrm{z}$ & Est. & $\mathrm{z}$ \\
\hline T3JOBSA ON SESMIG & .13 & .82 & .14 & .95 & -.17 & -.93 & .29 & 2.38 \\
\hline T3JOBSA ON T3SELF & .25 & 2.17 & .25 & 2.72 & .05 & .26 & .04 & .63 \\
\hline T3JOBSA ON T3PERUT & -.08 & -2.38 & .03 & .44 & -.02 & -.35 & -.16 & -3.17 \\
\hline T3JOBSA ON T3SOCUT & .15 & 4.19 & .15 & 3.30 & .14 & 3.92 & .16 & 3.41 \\
\hline T3JOBSA ON T3EFFPD & .01 & .08 & -.08 & -1.21 & -.13 & -1.30 & .01 & .14 \\
\hline T3JOBSA ON T3TPRA & -.03 & -.61 & .04 & .54 & -.01 & -.12 & -.11 & -1.80 \\
\hline T3JOBSA ON T3STUD & .25 & 4.32 & .27 & 5.68 & .28 & 2.04 & .42 & 8.33 \\
\hline T3TPRA ON TQ & -.02 & -.44 & .08 & 1.53 & .11 & 2.21 & .10 & 1.58 \\
\hline T3TPRA ON SESMIG & .12 & .78 & .00 & .01 & .08 & .67 & .26 & 1.85 \\
\hline T3TPRA ON T3EFFPD & -.02 & -.18 & -.07 & -.73 & -.14 & -1.72 & -.03 & -.20 \\
\hline T3TPRA ON T3SELF & .36 & 1.67 & .17 & 1.30 & .10 & .94 & .12 & .73 \\
\hline T3TPRA ON T3PERUT & .02 & .49 & .11 & 1.55 & .04 & 1.01 & -.08 & -1.17 \\
\hline T3TPRA ON T3SOCUT & .14 & 2.77 & .11 & 2.24 & .20 & 4.26 & .18 & 2.98 \\
\hline T3STUD ON TQ & .02 & 0.44 & .02 & .79 & .05 & .80 & -.05 & -1.42 \\
\hline T3STUD ON SESMIG & -.49 & -4.53 & -.50 & -8.43 & -.41 & -5.97 & -0.67 & -9.76 \\
\hline T3STUD ON T3EFFPD & -.01 & -.09 & .08 & 2.15 & .34 & 5.52 & .04 & .58 \\
\hline T3STUD ON T3SELF & .16 & 1.10 & .19 & 3.16 & .04 & .49 & .31 & 3.89 \\
\hline T3STUD ON T3PERUT & -.06 & -1.61 & .06 & 2.56 & .10 & 1.59 & .13 & 1.96 \\
\hline T3STUD ON T3SOCUT & .12 & 2.79 & .08 & 3.42 & .08 & 2.13 & .03 & .59 \\
\hline T3SELF ON TQ & -.11 & -2.35 & -.07 & -1.45 & -.04 & -.54 & .08 & 1.09 \\
\hline T3SELF ON SESMIG & -.75 & -7.95 & -.58 & -8.46 & -.80 & -15.34 & .34 & 1.97 \\
\hline T3SELF ON T3EFFPD & -.24 & -2.71 & .25 & 3.44 & -.01 & -.11 & .14 & 1.46 \\
\hline T3PERUT ON TQ & .09 & 2.50 & -.01 & -.27 & .14 & 2.57 & -.14 & -1.71 \\
\hline T3PERUT ON SESMIG & -.20 & -2.70 & -.18 & -1.98 & -.20 & -3.26 & -.08 & -.85 \\
\hline T3PERUT ON T3EFFPD & .19 & 2.48 & .20 & 2.46 & .04 & .49 & .35 & 4.29 \\
\hline T3SOCUT ON TQ & -.02 & -.58 & -.08 & -2.60 & -.04 & -.58 & -.11 & -1.67 \\
\hline T3SOCUT ON SESMIG & .13 & 1.31 & -.10 & -1.55 & -.16 & -2.78 & -.30 & -3.63 \\
\hline T3SOCUT ON T3EFFPD & .06 & .81 & .14 & 2.21 & -.08 & -1.01 & -.07 & -.72 \\
\hline T3EFFPD ON TQ & -.01 & -.08 & .00 & .01 & .04 & .60 & .08 & .86 \\
\hline T3EFFPD ON SESMIG & -.38 & -2.82 & -.44 & -5.51 & -.46 & -7.52 & -.27 & -2.40 \\
\hline
\end{tabular}




\section{Appendix E: Standardized Total Direct and Indirect Effects Among Variables in the Path Analysis for the Four Nordic Countries in TALIS 2018}

\begin{tabular}{|c|c|c|c|c|c|c|c|c|}
\hline \multirow{2}{*}{$\begin{array}{l}\text { Effects from TQ to } \\
\text { T3JOBSA }\end{array}$} & \multicolumn{2}{|l|}{ Denmark } & \multicolumn{2}{|l|}{ Finland } & \multicolumn{2}{|l|}{ Norway } & \multicolumn{2}{|l|}{ Sweden } \\
\hline & Estimate & $\mathrm{z}$ & Estimate & $\mathrm{z}$ & Estimate & $\mathrm{z}$ & Estimate & $\mathrm{z}$ \\
\hline Total & -.05 & -1.40 & -.06 & -1.45 & -.04 & -.63 & -.19 & -3.66 \\
\hline Total indirect & -.04 & -1.74 & -.03 & -1.51 & .00 & .11 & -.02 & -.64 \\
\hline Direct & -.01 & -.36 & -.03 & -.87 & -.05 & -.65 & -.16 & -3.26 \\
\hline \multicolumn{9}{|l|}{$\begin{array}{l}\text { Effects from } \\
\text { SESMIG to } \\
\text { T3JOBSA }\end{array}$} \\
\hline Total & -.14 & -1.03 & -.22 & -2.14 & -.34 & -3.80 & -.01 & -.11 \\
\hline Total indirect & -.27 & -3.50 & -.36 & -5.23 & -.16 & -1.30 & -.30 & -3.98 \\
\hline Direct & .13 & .82 & .14 & .95 & -.17 & -.93 & .29 & 2.38 \\
\hline \multicolumn{9}{|l|}{$\begin{array}{l}\text { Effects from } \\
\text { T3EFFPD To } \\
\text { T3JOBSA }\end{array}$} \\
\hline Total & -.07 & -.59 & .05 & .73 & -.05 & -.51 & .01 & .10 \\
\hline Total indirect & -.08 & -1.19 & .13 & 5.75 & .08 & 1.65 & .00 & .00 \\
\hline DIRECT & .01 & .08 & -.08 & -1.21 & -.13 & -1.30 & .01 & .14 \\
\hline \multicolumn{9}{|l|}{$\begin{array}{l}\text { Effects from } \\
\text { T3PERUT to } \\
\text { T3JOBSA }\end{array}$} \\
\hline Total & -.10 & -2.97 & .05 & .71 & .01 & .12 & -.10 & -1.63 \\
\hline Total indirect & -.02 & -1.51 & .02 & 2.24 & .03 & 1.08 & .06 & 1.85 \\
\hline Direct & -.08 & -2.38 & .03 & .44 & -.02 & -.35 & -.16 & -3.17 \\
\hline \multicolumn{9}{|l|}{$\begin{array}{l}\text { Effects from } \\
\text { T3SOCUT to } \\
\text { T3JOBSA }\end{array}$} \\
\hline Total & .17 & 4.95 & .17 & 3.97 & .16 & 3.97 & .15 & 2.90 \\
\hline Total indirect & .03 & 1.70 & .02 & 2.91 & .02 & 1.25 & -.01 & -.30 \\
\hline Direct & .15 & 4.19 & .15 & 3.30 & .14 & 3.92 & .16 & 3.41 \\
\hline \multicolumn{9}{|l|}{$\begin{array}{l}\text { Effects from T3SELF } \\
\text { to T3JOBSA }\end{array}$} \\
\hline Total & .28 & 2.38 & .31 & 3.92 & .06 & .31 & .15 & 1.57 \\
\hline Total indirect & .03 & .71 & .06 & 2.34 & .01 & .46 & .12 & 2.57 \\
\hline Direct & .25 & 2.17 & .25 & 2.72 & .05 & .26 & .04 & .63 \\
\hline
\end{tabular}




\section{Appendix F: Detailed Indirect Effect in the Operationalized Model in All Four NORDIC Countries in TALIS 2018}

\begin{tabular}{|c|c|c|c|c|c|c|c|c|}
\hline \multirow{2}{*}{$\begin{array}{l}\text { Path } \\
\text { Effects from TQ to T3JOBSA }\end{array}$} & \multicolumn{2}{|c|}{ Denmark } & \multicolumn{2}{|c|}{ Finland } & \multicolumn{2}{|c|}{ Norway } & \multicolumn{2}{|c|}{ Sweden } \\
\hline & Est. & $\mathrm{z}$ & Est. & $\mathrm{z}$ & Est. & $\mathrm{z}$ & Est. & $\mathrm{z}$ \\
\hline \multicolumn{9}{|l|}{ Specific indirect } \\
\hline TQ - T3SELF - T3JOBSA & -.03 & -1.57 & -.02 & -1.16 & .00 & -.23 & .00 & .55 \\
\hline TQ - T3PERUT - T3JOBSA & -.01 & -1.71 & .00 & -.20 & .00 & -.36 & .02 & 1.54 \\
\hline TQ - T3SOCUT - T3JOBSA & .00 & -.58 & -.01 & -1.99 & -.01 & -.57 & -.02 & -1.37 \\
\hline TQ - T3EFFPD - T3JOBSA & .00 & -.05 & .00 & -.01 & -.01 & -.58 & .00 & .13 \\
\hline TQ - T3TPRA - T3JOBSA & .00 & .31 & .00 & .56 & .00 & -.12 & -.01 & -1.01 \\
\hline TQ - T2STUD - T3JOBSA & .01 & .45 & .01 & .83 & .01 & .81 & -.02 & -1.37 \\
\hline $\begin{array}{l}\text { TQ - T3EFFPD - T3SELF - } \\
\text { T3JOBSA }\end{array}$ & .00 & .08 & .00 & .01 & .00 & -.09 & .00 & .45 \\
\hline $\begin{array}{l}\text { TQ - T3EFFPD - T3PERUT - } \\
\text { T3JOBSA }\end{array}$ & .00 & .08 & .00 & .01 & .00 & -.29 & -.01 & -.79 \\
\hline $\begin{array}{l}\text { TQ - T3EFFPD - T3SOCUT - } \\
\text { T3JOBSA }\end{array}$ & .00 & -.08 & .00 & .01 & .00 & -.46 & .00 & -.53 \\
\hline $\begin{array}{l}\text { TQ - T2SELF - T3TPRA - } \\
\text { T3JOBSA }\end{array}$ & .00 & .62 & .00 & -.54 & .00 & .12 & .00 & -.51 \\
\hline $\begin{array}{l}\text { TQ - T3PERUT - T3TPRA - } \\
\text { T3JOBSA }\end{array}$ & .00 & -.40 & .00 & -.21 & .00 & -.11 & .00 & -.81 \\
\hline $\begin{array}{l}\text { TQ - T3SOCUT - T3TPRA - } \\
\text { T3JOBSA }\end{array}$ & .00 & .39 & .00 & -.62 & .00 & .11 & .00 & 1.16 \\
\hline $\begin{array}{l}\text { TQ - T3EFFPD - T3TPRA - } \\
\text { T3JOBSA }\end{array}$ & .00 & -.08 & .00 & -.01 & .00 & .10 & .00 & .21 \\
\hline $\begin{array}{l}\text { TQ - T3SELF - T3STUD - } \\
\text { T3JOBSA }\end{array}$ & .00 & -.99 & .00 & -1.59 & .00 & -.38 & .01 & .98 \\
\hline $\begin{array}{l}\text { TQ - T3PERUT - T3STUD - } \\
\text { T3JOBSA }\end{array}$ & .00 & -1.33 & .00 & -.27 & .00 & 1.04 & -.01 & -1.16 \\
\hline $\begin{array}{l}\text { TQ - T3SOCUT - T3STUD - } \\
\text { T3JOBSA }\end{array}$ & .00 & -.60 & .00 & -2.21 & .00 & -.47 & .00 & -.51 \\
\hline $\begin{array}{l}\text { TQ - T3EFFPD - T3STUD - } \\
\text { T3JOBSA }\end{array}$ & .00 & .05 & .00 & .01 & .00 & .55 & .00 & .51 \\
\hline $\begin{array}{l}\text { TQ - T3EFFPD - T3SELF - } \\
\text { T3TPRA - T3JOBSA }\end{array}$ & .00 & -.08 & .00 & .01 & .00 & .07 & .00 & -.55 \\
\hline $\begin{array}{l}\text { TQ - T3EFFPD - T3PERUT - } \\
\text { T3TPRA - T3JOBSA }\end{array}$ & .00 & .07 & .00 & .01 & .00 & -.10 & .00 & .72 \\
\hline $\begin{array}{l}\text { TQ - T3EFFPD - T3SOCUT - } \\
\text { T3TPRA - T3JOBSA }\end{array}$ & .00 & .07 & .00 & .01 & .00 & .10 & .00 & .49 \\
\hline $\begin{array}{l}\text { TQ - T3EFFPD - T3SELF - } \\
\text { T3STUD - T3JOBSA }\end{array}$ & .00 & .08 & .00 & .01 & .00 & -.10 & .00 & .76 \\
\hline $\begin{array}{l}\text { TQ - T3EFFPD - T3PERUT - } \\
\text { T3STUD - T3JOBSA }\end{array}$ & .00 & .08 & .00 & .01 & .00 & .31 & .00 & .81 \\
\hline $\begin{array}{l}\text { TQ - T3EFFPD - T3SOCUT - } \\
\text { T3STUD - T3JOBSA }\end{array}$ & .00 & -.08 & .00 & .01 & .00 & -.43 & .00 & -.39 \\
\hline
\end{tabular}


5 Exploring Diversity in the Relationships Between Teacher Quality and Job Satisfacti... 131

\begin{tabular}{|c|c|c|c|c|c|c|c|c|}
\hline \multirow{2}{*}{$\begin{array}{l}\text { Path } \\
\text { Effects from TQ to T3JOBSA }\end{array}$} & \multicolumn{2}{|c|}{ Denmark } & \multicolumn{2}{|c|}{ Finland } & \multicolumn{2}{|c|}{ Norway } & \multicolumn{2}{|c|}{ Sweden } \\
\hline & Est. & $\mathrm{z}$ & Est. & $\mathrm{z}$ & Est. & $\mathrm{z}$ & Est. & $\mathrm{z}$ \\
\hline \multicolumn{9}{|l|}{ Effects from SESMIG to T3JOBSA } \\
\hline \multicolumn{9}{|l|}{ Specific indirect } \\
\hline SESMIG - T3SELF - T3JOBSA & -.19 & -2.16 & -.15 & -2.25 & -.04 & -.26 & .01 & .52 \\
\hline SESMIG - T3PERUT - T3JOBSA & .02 & 1.76 & -.01 & -.39 & .00 & .34 & .01 & .87 \\
\hline SESMIG - T3SOCUT - T3JOBSA & .02 & 1.24 & -.01 & -1.14 & -.02 & -2.31 & -.05 & -2.33 \\
\hline SESMIG - T3EFFPD - T3JOBSA & .00 & -.08 & .04 & 1.27 & .06 & 1.33 & .00 & -.14 \\
\hline SESMIG - T3TPRA - T3JOBSA & .00 & -.64 & .00 & .01 & .00 & -.12 & -.03 & -1.49 \\
\hline SESMIG - T3STUD - T3JOBSA & -.13 & -2.70 & -.14 & -4.46 & -.11 & -2.23 & -.28 & -5.97 \\
\hline $\begin{array}{l}\text { SESMIG - T3EFFPD - T3SELF - } \\
\text { T3JOBSA }\end{array}$ & .02 & 1.05 & -.03 & -3.04 & .00 & .09 & .00 & -.51 \\
\hline $\begin{array}{l}\text { SESMIG - T3EFFPD - } \\
\text { T3PERUT - T3JOBSA }\end{array}$ & .01 & 1.48 & .00 & -.50 & .00 & .33 & .02 & 1.68 \\
\hline $\begin{array}{l}\text { SESMIG - T3EFFPD - } \\
\text { T3SOCUT - T3JOBSA }\end{array}$ & .00 & -.75 & -.01 & -2.52 & .01 & .99 & .00 & .71 \\
\hline $\begin{array}{l}\text { SESMIG - T3SELF - T3TPRA - } \\
\text { T3JOBSA }\end{array}$ & .01 & .67 & .00 & -.53 & .00 & .12 & .00 & -.69 \\
\hline $\begin{array}{l}\text { SESMIG - T3PERUT - T3TPRA - } \\
\text { T3JOBSA }\end{array}$ & .00 & .41 & .00 & -.37 & .00 & .11 & .00 & -.66 \\
\hline $\begin{array}{l}\text { SESMIG - T3SOCUT - T3TPRA - } \\
\text { T3JOBSA }\end{array}$ & .00 & -.49 & .00 & -.69 & .00 & .12 & .01 & 1.31 \\
\hline $\begin{array}{l}\text { SESMIG - T3EFFPD - T3TPRA - } \\
\text { T3JOBSA }\end{array}$ & .00 & -.19 & .00 & .36 & .00 & -.11 & .00 & -.20 \\
\hline $\begin{array}{l}\text { SESMIG - T3SELF - T3STUD - } \\
\text { T3JOBSA }\end{array}$ & -.03 & -.99 & -.03 & -2.40 & -.01 & -.45 & .04 & 1.41 \\
\hline $\begin{array}{l}\text { SESMIG - T3PERUT - T3STUD - } \\
\text { T3JOBSA }\end{array}$ & .00 & 1.42 & .00 & -1.67 & -.01 & -1.17 & -.01 & -.70 \\
\hline $\begin{array}{l}\text { SESMIG - T3SOCUT - T3STUD - } \\
\text { T3JOBSA }\end{array}$ & .00 & 1.18 & .00 & -1.19 & .00 & -1.33 & .00 & -.56 \\
\hline $\begin{array}{l}\text { SESMIG - T3EFFPD - T3STUD - } \\
\text { T3JOBSA }\end{array}$ & .00 & .09 & -.01 & -2.19 & -.04 & -2.12 & -.01 & -.54 \\
\hline $\begin{array}{l}\text { SESMIG - T3EFFPD - T3SELF - } \\
\text { T3TPRA - T3JOBSA }\end{array}$ & .00 & -.55 & .00 & -.51 & .00 & -.07 & .00 & .68 \\
\hline $\begin{array}{l}\text { SESMIG - T3EFFPD - } \\
\text { T3PERUT - T3TPRA - T3JOBSA }\end{array}$ & .00 & .40 & .00 & -.48 & .00 & .11 & .00 & -.93 \\
\hline $\begin{array}{l}\text { SESMIG - T3EFFPD - } \\
\text { T3SOCUT - T3TPRA - T3JOBSA }\end{array}$ & .00 & .39 & .00 & -.54 & .00 & -.11 & .00 & -.64 \\
\hline $\begin{array}{l}\text { SESMIG - T3EFFPD - T3SELF - } \\
\text { T3STUD - T3JOBSA }\end{array}$ & .00 & .89 & -.01 & -1.64 & .00 & .11 & -.01 & -1.10 \\
\hline $\begin{array}{l}\text { SESMIG - T3EFFPD - } \\
\text { T3PERUT - T3STUD - T3JOBSA }\end{array}$ & .00 & 1.35 & .00 & -1.38 & .00 & -.40 & -.01 & -1.33 \\
\hline $\begin{array}{l}\text { SESMIG - T3EFFPD - } \\
\text { T3SOCUT - T3STUD - T3JOBSA }\end{array}$ & .00 & -.84 & .00 & -2.21 & .00 & .83 & .00 & .47 \\
\hline \multicolumn{9}{|l|}{$\begin{array}{l}\text { Effects from T3EFFPD To } \\
\text { T3JOBSA }\end{array}$} \\
\hline Specific indirect & & & & & & & & \\
\hline
\end{tabular}




\begin{tabular}{|c|c|c|c|c|c|c|c|c|}
\hline \multirow{2}{*}{$\begin{array}{l}\text { Path } \\
\text { Effects from TQ to T3JOBSA }\end{array}$} & \multicolumn{2}{|c|}{ Denmark } & \multicolumn{2}{|c|}{ Finland } & \multicolumn{2}{|c|}{ Norway } & \multicolumn{2}{|c|}{ Sweden } \\
\hline & Est. & $\mathrm{z}$ & Est. & $\mathrm{z}$ & Est. & $\mathrm{z}$ & Est. & $\mathrm{z}$ \\
\hline T3EFFPD - T3SELF - T3JOBSA & -.06 & -1.32 & .06 & 3.11 & .00 & -.09 & .01 & .55 \\
\hline T3EFFPD - T3PERUT - T3JOBSA & -.02 & -1.63 & .01 & .48 & .00 & -.33 & -.06 & -2.40 \\
\hline $\begin{array}{l}\text { T3EFFPD - T3SOCUT - } \\
\text { T3JOBSA }\end{array}$ & .01 & .75 & .02 & 2.88 & -.01 & -1.01 & -.01 & -.69 \\
\hline T3EFFPD - T3TPRA - T3JOBSA & .00 & .19 & .00 & -.35 & .00 & .11 & .00 & .21 \\
\hline T3EFFPD - T3STUD - T3JOBSA & .00 & -.09 & .02 & 2.58 & .10 & 2.13 & .02 & .60 \\
\hline $\begin{array}{l}\text { T3EFFPD - T3SELF - T3TPRA - } \\
\text { T3JOBSA }\end{array}$ & .00 & .60 & .00 & .50 & .00 & .07 & .00 & -.65 \\
\hline $\begin{array}{l}\text { T3EFFPD - T3PERUT - } \\
\text { T3TPRA - T3JOBSA }\end{array}$ & .00 & -.41 & .00 & .47 & .00 & -.11 & .00 & .93 \\
\hline $\begin{array}{l}\text { T3EFFPD - T3SOCUT - } \\
\text { T3TPRA - T3JOBSA }\end{array}$ & .00 & -.41 & .00 & .52 & .00 & .11 & .00 & .60 \\
\hline $\begin{array}{l}\text { T3EFFPD - T3SELF - T3STUD - } \\
\text { T3JOBSA }\end{array}$ & -.01 & -.95 & .01 & 1.74 & .00 & -.11 & .02 & 1.40 \\
\hline $\begin{array}{l}\text { T3EFFPD - T3PERUT - } \\
\text { T3STUD - T3JOBSA }\end{array}$ & .00 & -1.35 & .00 & 1.55 & .00 & .40 & .02 & 1.81 \\
\hline $\begin{array}{l}\text { T3EFFPD - T3SOCUT - } \\
\text { T3STUD - T3JOBSA }\end{array}$ & .00 & .81 & .00 & 2.13 & .00 & -.85 & .00 & -.45 \\
\hline \multicolumn{9}{|l|}{$\begin{array}{l}\text { Effects from T3PERUT to } \\
\text { T3JOBSA }\end{array}$} \\
\hline \multicolumn{9}{|l|}{ Specific indirect } \\
\hline T3PERUT - T3TPRA - T3JBSA & .00 & -.41 & .00 & .43 & .00 & -.11 & .01 & .97 \\
\hline T3PERUT - T3STUD - T3JOBSA & -.01 & -1.56 & .02 & 2.68 & .03 & 1.07 & .06 & 1.83 \\
\hline \multicolumn{9}{|l|}{$\begin{array}{l}\text { Effects from T3SOCUT to } \\
\text { T3JOBSA }\end{array}$} \\
\hline \multicolumn{9}{|l|}{ Specific indirect } \\
\hline T3SOCUT - T3TPRA - T3JOBSA & .00 & -.54 & .00 & .62 & .00 & -.11 & -.02 & -1.65 \\
\hline T3SOCUT - T3STUD - T3JOBSA & .03 & 2.46 & .02 & 3.44 & .02 & 1.33 & .01 & .59 \\
\hline \multicolumn{9}{|l|}{ Effects from T3SELF to T3JOBSA } \\
\hline \multicolumn{9}{|l|}{ Specific indirect } \\
\hline T3SELF - T3TPRA - T3JOBSA & -.01 & -.66 & .01 & .53 & .00 & -.12 & -.01 & -.62 \\
\hline T3SELF - T3STUD - T3JOBSA & .04 & 1.02 & .05 & 2.34 & .01 & .45 & .13 & 3.82 \\
\hline
\end{tabular}

\section{References}

Ahonen, S. (2014). A School for All in Finland. In: Blossing U., Imsen G., Moos L. (eds) The Nordic Education Model. Policy Implications of Research in Education (Vol 1). Dordrecht: Springer. https://doi.org/10.1007/978-94-007-7125-3_5.

Akiba, A., \& Liang, L. (2016). Effects of teacher professional learning activities on student achievement growth. The Journal of Educational Research, 109(1), 99-110. https://doi.org/1 0.1080/00220671.2014.924470

Alvunger, D., Sundberg, D., \& Wahlström, N. (2017). Teachers matter - But how? Journal of Curriculum Studies, 49(1), 1-6. https://doi.org/10.1080/00220272.2016.1205140 
Antikainen, A. (2006). In search of the Nordic model in education. Scandinavian Journal of Educational Research, 50(3), 229-243. https://doi.org/10.1080/00313830600743258

Aspfors, J., Hansen, S.-E., \& Ray, J. (2014). Stability, structure and development. Features constituting Finnish teacher education. Scuola Democratica, 12(3), 1-12. https://doi. org/10.12828/75800

Bandura, A. (1977). Self-efficacy: Toward a unifying theory of behavioral change. Psychological Review, 84(2), 191-215. https://doi.org/10.1037/0033-295X.84.2.191

Banerjee, N., Stearns, E., Moller, S., \& Mickelson, R. A. (2017). Teacher job satisfaction and student achievement: The roles of teacher professional community and teacher collaboration in schools. American Journal of Education, 123(2), 203-1241. https://doi.org/10.1086/689932

Baron, R. M., \& Kenny, D. A. (1986). The moderator-mediator variable distinction in social psychological research: Conceptual, strategic, and statistical considerations. Journal of Personality and Social Psychology, 51(6), 1173. https://doi.org/10.1037/0022-3514.51.6.1173

Baumert, J., Kunter, M., Blum, W., Brunner, M., Voss, T., Jordan, A., et al. (2009). Teachers' mathematical knowledge, cognitive activation in the classroom, and student progress. American Educational Research Journal, 47(1), 133-180. https://doi.org/10.3102/0002831209345157

Berger, J.-L., \& Lê Van, K. (2019). Teacher professional identity as multidimensional: Mapping its components and examining their associations with general pedagogical beliefs. Educational Studies, 45(2), 163-1181. https://doi.org/10.1080/03055698.2018.1446324

Blömeke, S., Gustafsson, J.-E., \& Shavelson, R. J. (2015). Beyond dichotomies: Competence viewed as a continuum. Zeitschrift für Psychologie, 223(1), 3-13. https://doi. org/10.1027/2151-2604/a000194

Blömeke, S., Olsen, R. V., \& Suhl, U. (2016). Relation of student achievement to the quality of their teachers and instructional quality. In T. Nilsen \& J.-E. Gustafsson (Eds.), Teacher quality, instructional quality and student outcomes (IEA Research for Education 2) (pp. 21-50). Cham, Switzerland: Springer.

Blossing, U., Imsen, G., \& Moos, L. (2014). Nordic schools in a time of change. In U. Blossing, G. Imsen, \& L. Moos (Eds.), The Nordic education model. Policy implications of research in education (Vol. 1, pp. 1-114). Dordrecht, The Netherlands: Springer.

Blossing, U., \& Söderström, Å. (2014). A school for every child in Sweden. In U. Blossing, G. Imsen, \& L. Moos (Eds.), The Nordic education model. Policy implications of research in education (Vol. 1, pp. 17-134). Dordrecht, The Netherlands: Springer.

Bourdieu, P. (1990). Structures, habitus, practices. In The logic of practice (pp. 52-65). Cambridge, UK: Polity.

Buehl, M. M., \& Beck, J. (2015). The relationship between teachers' beliefs and practices. In H. Fives \& M. G. Gregorie (Eds.), International handbook of research on teachers' beliefs (pp. 66-184). New York: Routledge.

Caprara, G. V., Barbaranelli, C., Borgogni, L., \& Steca, P. (2003). Efficacy beliefs as determinants of teachers' job satisfaction. Journal of Educational Psychology, 95(4), 821-832. https://doi. org/10.1037/0022-0663.95.4.821

Caprara, G. V., Barbaranelli, C., Steca, P., \& Malone, P. S. (2006). Teachers' self-efficacy beliefs as determinants of job satisfaction and students' academic achievement: A study at the school level. Journal of School Psychology, 44(6), 473-1490. https://doi.org/10.1016/j.jsp.2006.09.001

Chesnut, S. R., \& Burley, H. (2015). Self-efficacy as a predictor of commitment to the teaching profession: A meta-analysis. Educational Research Review, 15, 1-16. https://doi.org/10.1016/j. edurev.2015.02.001

Chmielewski, A. K. (2019). The global increase in the socioeconomic achievement gap, 1964 to 2015. American Sociological Review, 84(3), 517-544. https://doi. org/10.1177/0003122419847165

Coleman, J. S., Campbell, E., Hobson, C., McPartland, J., Mood, A., Weinfeld, F., et al. (1966). Equality of educational opportunity. Washington, DC: US Government Printing Office. 
Collie, R. J., Shapka, J. D., \& Perry, N. E. (2012). School climate and social-emotional learning: Predicting teacher stress, job satisfaction, and teaching efficacy. Journal of Educational Psychology, 104(4), 1189-11204. https://doi.org/10.1037/a0029356

Correnti, R. (2007). An empirical investigation of professional development effects on literacy instruction using daily logs. Educational Evaluation and Policy Analysis, 29(4), 262-1295. https://doi.org/10.3102/0162373707309074

Darling-Hammond, L. (2017). Teacher education around the world: What can we learn from international practice? European Journal of Teacher Education, 40(3), 1-19. https://doi.org/10.108 0/02619768.2017.1315399

Dellinger, A. B., Bobbett, J. J., Olivier, D. F., \& Ellett, C. D. (2008). Measuring teachers' selfefficacy beliefs: development and use of the TEBS-Self. Teaching and Teacher Education, 24(3), 751-1766. https://doi.org/10.1016/j.tate.2007.02.010

Desimone, L., Smith, T. M., \& Phillips, K. (2013). Linking student achievement growth to professional development participation and changes in instruction: A longitudinal study of elementary students and teachers in title I schools. Teachers College Record, 115(5), 1-146.

Dicke, T., Marsh, H. W., Parker, P. D., Guo, J., Riley, P., \& Waldeyer, J. (2020). Job satisfaction of teachers and their principals in relation to climate and student achievement. Journal of Educational Psychology, 112(5), 1061-1073. https://doi.org/10.1037/edu0000409

Eccles, J. S., \& Wigfield, A. (2002). Motivational beliefs, values, and goals. Annual review of psychology, 53(1), 109-132. https://doi.org/10.1146/annurev.psych.53.100901.135153.

Espinoza, O. (2007). Solving the equity-equality conceptual dilemma: a new model for analysis of the educational process. Educational Research, 49(4), 343-363. https://doi. org/10.1080/00131880701717198.

Ferguson, K., Frost, L., \& Hall, D. (2012). Predicting teacher anxiety, depression, and job satisfaction. Journal of Teaching and Learning, 8(1), 27-142. https://doi.org/10.22329/jtl.v8i1.2896

Fischer, C., Fishman, B., Dede, C., Eisenkraft, A., Frumin, K., Foster, B., et al. (2018). Investigating relationships between school context, teacher professional development, teaching practices, and student achievement in response to a nationwide science reform. Teaching and Teacher Education, 72, 107-1121. https://doi.org/10.1016/j.tate.2018.02.011

Gil-Flores, J. (2017). The role of personal characteristics and school characteristics in explaining teacher job satisfaction. Revista de Psicodidáctica, 22(1), 16-22. https://doi.org/10.1387/ RevPsicodidact. 15501

Goe, L. (2007). The link between teacher quality and student outcomes: A research synthesis. Washington, DC, USA: National Comprehensive Center for Teacher Quality. Retrieved from: http://www.gtlcenter.org/sites/default/files/docs/LinkBetweenTQandStudentOutcomes.pdf.

Griffith, J. (2004). Relation of principal transformational leadership to school staff job satisfaction, staff turnover, and school performance. Journal of Educational Administration, 42(3), 333-356. https://doi.org/10.1108/09578230410534667

Gustafsson, J.-E., \& Blömeke, S. (2018). Development of school achievement in the Nordic countries during half a century. Scandinavian Journal of Educational Research, 62(3), 386-1406. https://doi.org/10.1080/00313831.2018.1434829

Hanushek, E. A. (2008). Education production functions. In P. Newman (Ed.), The new Palgrave dictionary of economics. London: Palgrave Macmillan.

Hanushek, E. A., \& Rivkin, S. G. (2012). The distribution of teacher quality and implications for policy. Annual Review of Economics, 4(1), 131-157. https://doi.org/10.1146/ annurev-economics-080511-111001

Husén, T. (1989). The Swedish school reform-Exemplary both ways. Comparative Education, 25(3), 345-1355. https://doi.org/10.1080/0305006890250311

Imsen, G., Blossing, U., \& Moos, L. (2017). Reshaping the Nordic education model in an era of efficiency. Changes in the comprehensive school project in Denmark, Norway, and Sweden since the millennium. Scandinavian Journal of Educational Research, 61(5), 568-1583. https://doi.org/10.1080/00313831.2016.1172502 
Imsen, G., \& Volckmar, N. (2014). The Norwegian school for all: Historical emergence and neoliberal confrontation. In U. Blossing, G. Imsen, \& L. Moos (Eds.), The Nordic education model. Policy implications of research in education (Vol. 1, pp. 35-155). Dordrecht, The Netherlands: Springer.

Klassen, R. M., \& Tze, V. M. C. (2014). Teachers' self-efficacy, personality, and teaching effectiveness: A meta-analysis. Educational Research Review, 12, 59-76. https://doi.org/10.1016/j. edurev.2014.06.001

König, J., Lammerding, S., Nold, G., Rohde, A., Strauß, S., \& Tachtsoglou, S. (2016). Teachers' professional knowledge for teaching English as a foreign language: Assessing the outcomes of teacher education. Journal of Teacher Education, 67(4), 320-337. https://doi. org/10.1177/0022487116644956

Liu, Y., \& Verblow, J. (2019). The operation of distributed leadership and the relationship with organisational commitment and job satisfaction of principals and teachers: A multi-level model and meta-analysis using the 2013 TALIS data. International Journal of Educational Research, 96, 41-55. https://doi.org/10.1016/j.ijer.2019.05.005

Lundahl, L. (2016). Equality, inclusion and marketisation of Nordic education: Introductory notes. Research in Comparative and International Education, 11(1), 3-12. https://doi. org $/ 10.1177 / 0022487116644956$

Matsumura, L. C., Garnier, H. E., \& Resnick, L. B. (2010). Implementing literacy coaching: The role of school social resources. Educational Evaluation and Policy Analysis, 32(2), 249-272. https://doi.org/10.3102/0162373710363743

Matsuoka, R. (2015). School socioeconomic context and teacher job satisfaction in Japanese compulsory education. Educational Studies in Japan: International Yearbook, 9, 41-54.

Muthén, L. K., \& Muthén, B. O. (1998-2017). Mplus user's guide (8th ed.). Los Angeles: Muthén \& Muthén.

Nie, Y., Tan, G. H., Liau, A. K., Lau, S., \& Chua, B. L. (2012). The roles of teacher efficacy in instructional innovation: Its predictive relations to constructivist and didactic instruction. Educational Research for Policy and Practice, 12(1), 67-77. https://doi.org/10.1007/ s10671-012-9128-y

Nye, B., Konstantopoulos, S., \& Hedges, L. V. (2004). How large are teacher effects? Educational Evaluation and Policy Analysis, 26(3), 237-257. https://doi.org/10.3102/01623737026003237

OECD. (2013a). TALIS 2013 Conceptual framework. OECD Publishing. https://www.oecd.org/ education/school/TALIS20ConceptualFramework_FINAL.pdf

OECD. (2013b). TALIS 2013 technical report. OECD Publishing. http://www.oecd.org/education/ school/TALIS-technical-report-2013.pdf

OECD. (2018). Equity in education: Breaking down barriers to social mobility. PISA, OECD Publishing. https://doi.org/10.1787/9789264073234-en

OECD. (2019a). PISA 2018 results (volume I): What students know and can do? OECD Publishing. https://doi.org/10.1787/5f07c754-en.

OECD. (2019b). TALIS 2018 results (volume I): Teachers and school leaders as lifelong learners. TALIS, OECD Publishing. https://doi.org/10.1787/1d0bc92a-en

OECD. (2019c). TALIS 2018 technical report. OECD Publishing. https://www.oecd.org/education/talis/TALIS_2018_Technical_Report.pdf

Pajares, F. (1992). Teachers' beliefs and educational research: Cleaning up a messy construct. Review of Educational Research, 62(3), 307-332. https://doi.org/10.3102/00346543062003307

Penuel, W. R., Fishman, B., Yamaguchi, R., \& Gallagher, L. P. (2007). What makes professional development effective? Strategies that foster curriculum implementation. American Educational Research Journal, 44(4), 921-958. https://doi.org/10.3102/0002831207308221

Rasmussen, A., \& Moos, L. (2014). A school for less than all in Denmark. In U. Blossing, G. Imsen, \& L. Moos (Eds.), The Nordic education model. Policy implications of research in education (Vol. 1, pp. 57-75). Dordrecht, The Netherlands: Springer. 
Reimer, D. (2019). Teachers and teacher education: A call for a renewed sociological research agenda. International Studies in Sociology of Education, 28(2), 90-109. https://doi.org/10.108 0/09620214.2019.1601582

Reimer, D., Sortkear, B., Oskarsson, M., Nilsen, T., Rasmusson, M., \& Nissinen, K. (2018). Northern Lights on TIMSS and PISA 2018. Copenhagen: Nordic Council of Ministers. https:// doi.org/10.6027/TN2018-524.

Richardson, P. W., \& Watt, H. M. (2006). Who chooses teaching and why? Profiling characteristics and motivations across three Australian universities. Asia-Pacific Journal of Teacher Education, 34(1), 27-56. https://doi.org/10.1080/13598660500480290

Richardson, P. W., \& Watt, H. M. G. (2016). Factors influencing teaching choice: Why do future teachers choose the career? In J. Loughran, \& M. L. Hamilton (Eds.), International Handbook of Teacher Education (Vol. 2, pp. 275-304). Springer. https://doi. org/10.1007/978-981-10-0369-1_8

Roth, K. J., Garnier, H. E., Chen, C., Lemmens, M., Schwille, K., \& Wickler, N. I. Z. (2011). Video-based lesson analysis: Effective science PD for teacher and student learning. Journal of Research in Science Teaching, 48(2), 117-148. https://doi.org/10.1002/tea.20408

Ryan, R. M., \& Deci, E. L. (2000). Self-determination theory and the facilitation of intrinsic motivation, social development, and well-being. American Psychologist, 55(1), 68-78. https://doi. org/10.1037/0003-066X.55.1.68

Scherer, R., \& Nilsen, T. (2016). The relations among school climate, instructional quality, and achievement motivation in mathematics. In T. Nilsen \& J.-E. Gustafsson (Eds.), Teacher quality, instructional quality and student outcomes (pp. 51-80). Springer. https://doi. org/10.1007/978-3-319-41252-8_3

Schwab, S. (2019). Teachers' student-specific self-efficacy in relation to teacher and student variables. Educational Psychology, 39(1), 4-18. https://doi.org/10.1080/01443410.2018.1516861

Shulman, L. S. (1986). Those who understand: A conception of teacher knowledge. American Educator, 10(1), 9-15. http://www.jstor.org/stable/1175860

Shulman, L. S. (1987). Knowledge and teaching: Foundations of the new reform. Harvard Educational Review, 57(1), 1-23. https://doi.org/10.17763/haer.57.1.j463w79r56455411

Skaalvik, E. M., \& Skaalvik, S. (2009). Does school context matter? Relations with teacher burnout and job satisfaction. Teacher and Teacher Education, 25(3), 518-524. https://doi. org/10.1016/j.tate.2008.12.006

Skaalvik, E. M., \& Skaalvik, S. (2014). Teacher self-efficacy and perceived autonomy: Relations with teacher engagement, job satisfaction, and emotional exhaustion. Psychological Reports, 114(1), 68-77. https://doi.org/10.2466/14.02.PR0.114k14w0

Taajamo, M. (2016). Teachers' professional development in Nordic countries. In Northern Lights on PISA and TALIS (pp. 101-133). Nordic Council of Ministers.

Torsney, B. M., Lombardi, D., \& Ponnock, A. (2019). The role of values in pre-service teachers' intentions for professional engagement. Educational Psychology, 39(1), 19-37. https://doi. org/10.1080/01443410.2018.1504892

Varghese, C., Garwood, J. D., Bratsch-Hines, M., \& Vernon-Feagans, L. (2016). Exploring magnitude of change in teacher efficacy and implications for students' literacy growth. Teaching and Teacher Education, 55, 228-239. https://doi.org/10.1016/j.tate.2016.01.011

Veldman, I., van Tartwijk, J., Brekelmans, M., \& Wubbels, T. (2013). Job satisfaction and teacherstudent relationships across the teaching career: Four case studies. Teaching and Teacher Education, 32, 55-65. https://doi.org/10.1016/j.tate.2013.01.005

Vieluf, S., Kuenther, M., \& van de Vijver, F. J. R. (2013). Teacher self-efficacy in cross-cultural perspective. Teaching and Teacher Education: An International Journal of Research and Studies, 35, 92-103. https://doi.org/10.1016/j.tate.2013.05.006

Volckmar, N., \& Wiborg, S. (2014). A social democratic response to market-led education policies: Concession or rejection? In U. Blossing, G. Imsen, \& L. Moos (Eds.), The Nordic education model. Policy implications of research in education (Vol. 1, pp. 117-131). Dordrecht, The Netherlands: Springer. 
Wallenius, T., Juvonen, S., Hansen, P., \& Varjo, J. (2018). Schools, accountability and transparency-Approaching the Nordic school evaluation practices through discursive institutionalism. Nordic Journal of Studies in Educational Policy, 4(3), 133-143. https://doi.org/10.108 0/20020317.2018.1537432

Wang, K., Chen, Z., Luo, W., Li, Y., \& Waxman, H. (2018). Examining the differences between the job satisfaction of STEM and non-STEM novice teachers with leaving intentions. EURASIA Journal of Mathematics, Science and Technology Education, 14(6), 2329-2341. https://doi. org/10.29333/ejmste/89516

Wang, K., Li, Y., Luo, W., \& Zhang, S. (2019). Selected factors contributing to teacher job satisfaction: A quantitative investigation using 2013 TALIS data. Leadership and Policy in Schools. https://doi.org/10.1080/15700763.2019.1586963

Wolfle, L. M. (1980). Strategies of path analysis. American Educational Research Journal, 17(2), 183-209. https://doi.org/10.3102/00028312017002183

Wollscheid, S., \& Opheim, V. (2016). Knowledge brokering initiatives in education - A systematic map of the Nordic countries. Nordic Journal of Studies in Educational Policy, 2016(1), 31111. https://doi.org/10.3402/nstep.v2.31111

Zee, M., \& Koomen, H. M. T. (2016). Teacher self-efficacy and its effects on classrooms processes, student academic adjustment, and teacher well-being: A synthesis of 40 years of research. Review of Educational Research, 86(4), 981-1015. https://doi.org/10.3102/0034654315626801

Open Access This chapter is licensed under the terms of the Creative Commons Attribution 4.0 International License (http://creativecommons.org/licenses/by/4.0/), which permits use, sharing, adaptation, distribution and reproduction in any medium or format, as long as you give appropriate credit to the original author(s) and the source, provide a link to the Creative Commons license and indicate if changes were made.

The images or other third party material in this chapter are included in the chapter's Creative Commons license, unless indicated otherwise in a credit line to the material. If material is not included in the chapter's Creative Commons license and your intended use is not permitted by statutory regulation or exceeds the permitted use, you will need to obtain permission directly from the copyright holder.

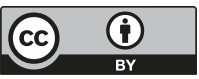

